\title{
Cash Windfalls and Acquisitions
}

von Beschwitz, Bastian
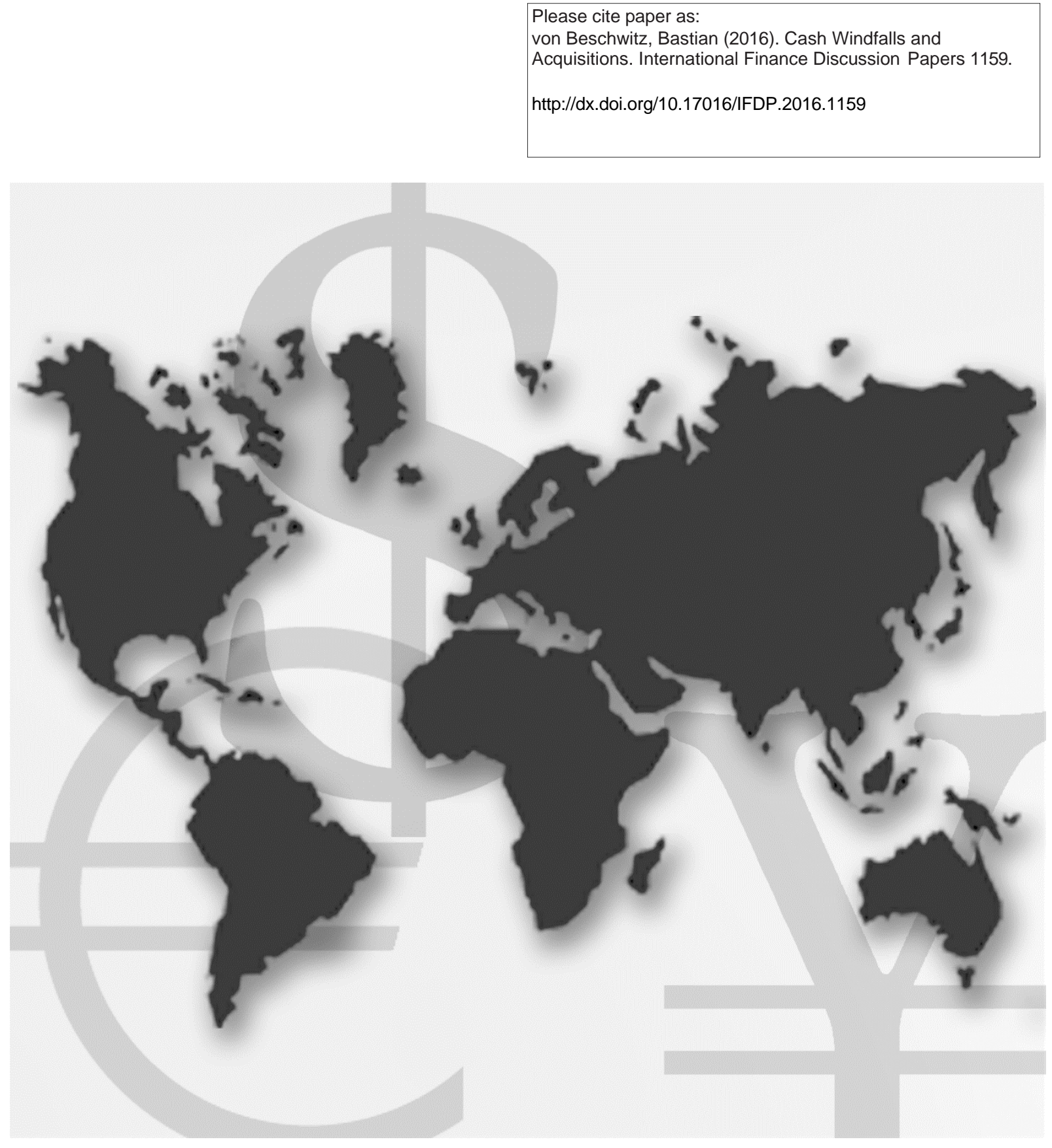

\section{International Finance Discussion Papers}

Board of Governors of the Federal Reserve System

Number 1159

February 2016 
Board of Governors of the Federal Reserve System

International Finance Discussion Papers

Number 1159

February 2016

\section{Cash Windfalls and Acquisitions}

Bastian von Beschwitz

NOTE: International Finance Discussion Papers are preliminary materials circulated to stimulate discussion and critical comment. References to International Finance Discussion Papers (other than an acknowledgment that the writer has had access to unpublished material) should be cleared with the author or authors. Recent IFDPs are available on the Web at www.federalreserve.gov/pubs/ifdp/. This paper can be downloaded without charge from the Social Science Research Network electronic library at www.ssrn.com. 


\title{
Cash Windfalls and Acquisitions
}

\author{
Bastian von Beschwitz*
}

\begin{abstract}
This article studies the effect of cash windfalls on the acquisition policy of companies. As identification I use a German tax reform that permitted firms to sell their equity stakes tax-free. Companies that could realize a cash windfall by selling equity stakes see an increase in the probability of acquiring another company by 19 percent. I find that these additional acquisitions destroy firm value. Following the tax reform, affected firms experience a decrease of 1.2 percentage points in acquisition announcement returns. These effects are stronger for larger cash windfalls. My findings are consistent with the free cash flow theory.
\end{abstract}

Keywords: Acquisitions, Free Cash Flow Theory, Overinvestment

JEL classifications: G30, G31, G34

\footnotetext{
* Bastian von Beschwitz, Federal Reserve Board, International Finance Division, 20th Street and Constitution Avenue N.W. Washington, D.C. 20551, tel. +1 202475 6330, e-mail: bastian.vonbeschwitz@gmail.com.

I thank the INSEAD Alumni Fund (IAF) for generous financial support. I have benefited greatly from feedback provided by Mark Carey, Stijn Claessens, Jean Dermine, Maria Guadalupe, Todd Gormley, Denis Gromb, Katharina Lewellen, Mathieu Luypaert, Massimo Massa, Holger Mueller, Urs Peyer, Hannes Wagner, Stefan Zeume and seminar participants at INSEAD and the DGF 2012. The views in this paper are solely the responsibility of the author and should not be interpreted as reflecting the views of the Board of Governors of the Federal Reserve System or of any other person associated with the Federal Reserve System.
} 


\section{Introduction}

How access to financing affects a firm's investment policy is one of the fundamental questions in corporate finance. As Stein (2003) points out, there is convincing evidence that firms with a strong financial position invest more, but it is less clear whether this effect is driven by underor overinvestment. Underinvestment occurs if financial frictions prevent management from making value increasing investments (e.g. Myers and Majluf (1984)). While, overinvestment occurs if managers engage in "empire building” (Baumol (1959), Williamson (1964)) as predicted by the free cash flow theory (Jensen (1986)). Answering this question is difficult for two reasons: First, it is generally hard to determine whether an investment project creates value to shareholders. Second, internal financial resources and investment opportunities are typically correlated, making any simple cross-sectional study subject to endogeneity concerns. ${ }^{1}$

In this paper, I address these issues by studying the effect of large exogenous cash windfalls on a firm's acquisition activity. The cash windfalls resulted from a German tax reform that made divestitures of equity stakes tax-free. Since not all firms owned equity stakes, the tax reform provided cash windfalls only to a subset of firms. Using difference-in-difference estimation, I find that firms receiving a cash windfall undertake more acquisitions and that the additional acquisitions have negative announcement returns, consistent with overinvestment.

In addition to showing evidence of overinvestment, my paper adds to the literature on asset sales. Despite the fact that U.S. firms raise more financing through asset sales than through equity issuance (Edmans and Mann (2013)), this financing channel has received little attention in the academic literature. In particular, while there is evidence that asset sales are correlated with higher investments (Hovakimian and Titman (2006), Borisova and Brown (2013)), my paper is the first to address endogeneity by exploiting an exogenous shock to firms' ability to sell assets.

This exogenous shock is provided by the German capital gains tax reform in 2000. Before the reform, many German corporations held minority equity stakes in unrelated firms. These equity stakes often had high market values, making up a sizeable part of the holder's assets. For example, the telecommunications and energy company VIAG owned equity stakes with a (pretax) market value of EUR 2.9 billion (25 percent of its own market capitalization) at the end of 1999. Many of these holdings had been established in the 1950s and 1960s and thus had

\footnotetext{
${ }^{1}$ There has been an intensive debate on how to interpret the findings of investment cash flow regressions (Fazzari, Hubbard and Petersen (2000), Kaplan and Zingales (1997), Kaplan and Zingales (2000), Erickson and Whited (2000), Gomes (2001), Alti (2003), Moyen (2004)).
} 
accumulated large capital gains. Consequently, firms had strong incentives to maintain these equity stakes to avoid capital gains taxation (Sautner and Villalonga (2010)). The German government decided to abolish the 50 percent capital gains tax in 2000, thus removing a major obstacle to the divestiture of the equity stakes.

I show that stock prices of firms with large equity stakes increased by 4 percent upon the announcement of the tax reform (see Figure 1), which suggests that the reform was a surprise to the market and that the tax acted as a binding constraint on firms. After the tax reform, this constraint was lifted and firms cashed in their equity stakes. I refer to the resulting cash inflows as windfalls, because the capital gains tax effectively prevented a sale of the equity stakes before the tax reform and because the tax reform is exogenous to the investment opportunities of an individual firm.

Firms with better investment opportunities are potentially more likely to sell their equity stakes to finance new investments. Therefore, I do not condition on the actual divesting decision but on the existence of an equity stake prior to the reform (as in Frydman and Hilt (2010)), i.e. my treatment group are firms with equity stakes in 1999 and the control group are firms without equity stakes. This approximation is reasonable as 83 percent of companies divested at least one of their equity stakes and including the other 17 percent only underestimates the true effect.

Do firms use the windfalls from selling equity stakes to undertake more acquisitions? Media reports suggest that this may be the case. For example, the Wirtschafts Woche, a leading German business magazine, wrote in February 2005:

The cross-holdings lock up capital which is needed to stay competitive internationally. The energy company E.ON sold several equity stakes [...] as it needs the money for acquisitions abroad. - -Wirtschafts Woche 04.02.2005. ${ }^{2}$

My analyses suggest that E.ON is not the only firm to finance acquisitions by divesting equity stakes. A simple comparison of means reveals that the yearly probability of doing an acquisition increases by 19 percent (7 percentage points) for firms that hold equity stakes before the tax reform (and thus receive a potential cash windfall), but decreases by 1.2 percentage points for the control group. A more elaborate difference-in-difference analysis confirms these results by showing that firms with equity stakes in 1999 increase their probability of

2 “Der Umbau der Deutschland AG” Wirtschafts Woche 04.02.2005

http://www.wiwo.de/unternehmen/sinnvolle-loesungen-der-umbau-der-deutschland-ag/4902614.html 
undertaking an acquisition by 8 percentage points relative to the control group. This finding rejects the perfect capital market assumption of Modigliani and Miller (1958).

Next, I study the acquirer announcement returns to determine whether the additional acquisitions represent overinvestment (free cash flow theory) or a reduction in underinvestment (financial constraints theory). I conduct a difference-in-difference analysis on the acquirer announcement returns. Companies that owned equity stakes at the time of the tax reform experience a decrease in average announcement returns relative to the control group of 1.2 percentage points. This finding is consistent with overinvestment.

However, because average announcement returns remain positive after the tax reform, one may be concerned that the decrease in announcement returns can be explained by decreasing but still positive marginal returns. ${ }^{3}$ I address this concern in two ways: First, I show in a simple calculation that the decrease in average announcement returns is so large that the additional acquisitions must have negative announcement returns. Second, I examine the sum of the announcement returns of all acquisitions a company undertakes over a year (following Bertrand and Mullainathan (2005)). If the additional acquisitions have positive announcement returns, they should increase the sum of announcement returns. However, after the tax reform, the yearly sum of all announcement returns of acquisitions completed by firms with cash windfalls decreases by 0.6 percent relative to the control group. This implies that the additional acquisitions destroy 0.6 percent of firm value per year or 4.8 percent over our sample period. These findings suggest that the cash windfalls are used for overinvestment as predicted by the free cash flow theory.

Next, I study for which firms our results are largest. We would expect the tax reform to have a stronger effect on firms receiving larger cash windfalls. Indeed, I find that my results are largely driven by firms who rank above the median by value of their equity stakes before the tax reform (as a share of their market capitalization). These firms see an increase in acquisition probability of 11 percentage points, while it is only 5 percentage points for firms below the median. Also the reduction in average announcement returns is larger for firms with large equity stakes (2 percent vs. 1 percent).

\footnotetext{
${ }^{3}$ Like other studies on acquisitions in Europe (Faccio, McConnell and Stolin (2006), Huyghebaert and Luypaert (2009)), I find positive acquirer announcement returns. Even in the U.S. the average acquisition has a positive announcement return for acquirers, but large acquisitions with negative returns make the volume weighted acquisition return negative (Moeller, Schlingemann and Stulz (2005)).
} 
I also show that the results are bigger for firms that sold a larger fraction of their equity stakes. While this analysis is affected by the endogeneity concerns outlined above, it is still comforting to see that the effect goes in the right direction.

All results are robust to controlling for different trends in firm characteristics such as size, Tobin's Q or leverage as well as industry-year fixed effects. They are also robust to running the regressions on a control sample matched by size and industry as well as using a shorter event window. As expected, running a placebo test in which we pretend the tax reform happened in 1995, we do not find any significant results.

One concern is that the additional acquisitions may substitute for capital expenditures. I show that this is not the case. In addition to the increase in acquisition activity, firms receiving cash windfalls increase capital expenditures as a share of assets by 0.7 percentage points. While this is not statistically significant, it constitutes an increase of $13 \%$ relative to the sample median. In contrast, dividends are not increased by firms receiving cash windfalls.

Taken together, my results suggest that firms do not pay out the cash windfall to shareholders, but rather invest it in value-destroying acquisitions. Therefore, my results are consistent with the free cash flow theory and empire building of managers.

My paper has important policy implications. It shows that the tax reform succeeded in allowing firms to divest their equity stakes and in freeing up capital for additional investments. However, my results also suggest that these investments constituted overinvestment, which destroyed shareholder value.

My paper is related to two streams of literature. The literature on investment and the literature on asset sales. ${ }^{4}$ The investment literature started by studying the relationship between investment and cash flows directly (e.g. Fazzari et al. (1988), Hoshi, Kashyap and Scharfstein (1990), Whited (1992), Almeida and Campello (2007)). Several studies also focus on acquisitions and investment projects: Lang, Stulz and Walkling (1991) show that low q firms with high cash flows exhibit lower acquirer announcement returns. Harford (1999) shows that firms with excess cash undertake more acquisitions, which are less profitable. Bertrand and Mullainathan (2005) find that oil companies with higher cash flows bid more for oil and gas

\footnotetext{
${ }^{4}$ My paper also relates to another stream of literature studying the marginal value of cash in a company (Pinkowitz, Stulz and Williamson (2006), Faulkender and Wang (2006), Dittmar and Mahrt-Smith (2007), Frésard and Salva (2010)) and how companies accumulate and use cash reserves (Opler et al. (1999), Dittmar, Mahrt-Smith and Servaes (2003), Almeida, Campello and Weisbach (2004), Harford, Mansi and Maxwell (2008), Bates, Kahle and Stulz (2009), Denis and Sibilkov (2010)). I add to these papers by studying the effect of cash windfalls, which are exogenous to investment opportunities.
} 
leases, but do not bid on more leases. However, all these studies are to some degree subject to endogeneity concerns: Firms potentially hoard cash in anticipation of future acquisitions and cash flows are correlated with investment opportunities.

Therefore, more recent papers focus on shocks to financial resources which are exogenous to the company's investment opportunities: Rauh (2006) uses the nonlinearities of mandatory pension contributions to show that exogenous cash outflows cause a decrease in capital expenditures, acquisitions and dividends. ${ }^{5}$ However, Bakke and Whited (2012) show that the methodology employed in Rauh (2006) is not sufficient to account for the endogeneity of mandatory pension contributions. Using a refined approach, they find no causal effect on investments. Other papers study shocks transmitted through the financing channel (e.g. Gan (2007), Chaney, Sraer and Thesmar (2009), Almeida et al. (2009), Chava and Purnanandam (2011)). I make two important contributions to this literature. First, I use cash windfalls rather than cash outflows. This difference is important: If shareholders want to restrict the free cash in the company, they finance it just sufficiently to undertake all profitable projects. In this case, the negative effect of an unexpected cash outflow on investment does not necessarily imply a positive effect of a cash windfall. Second, I focus on acquisitions, which allows me to examine the value effect of the additional investments through announcement returns. Thus, I can distinguish between the free cash flow theory and non-agency theories of financial constraints. Very few paper look at cash windfalls. Blanchard, Lopez-de-Silanes and Shleifer (1994) study cash windfalls of won or settled lawsuits, but cannot make any statistical inference, because their study only includes 11 companies. Faulkender and Peterson (2012) find that constrained firms invest more after a tax holiday on repatriated foreign earnings. However, the law granting the tax holiday included regulations forcing firms to invest the repatriated earnings (Dharmapala, Foley and Forbes (2011)). Thus, it is not clear whether their findings extend to cash windfalls more generally or was just a result of the specific law.

Second, I add to the literature studying asset sales as a financing channel. This literature is surprisingly small, given that U.S. firms raise more financing through asset sales than through equity issuance (Edmans and Mann (2013)). The literature include Bates (2005), who finds that firms with better investment opportunities are more likely to retain the proceeds of assets sales. Furthermore, financially constraint firms have a stronger sensitivity between the proceeds of asset sales and both investment (Hovakimian and Titman (2006)) and R\&D (Borisova and

\footnotetext{
${ }^{5}$ Following the approach in Rauh (2006), Franzoni (2009) estimate the stock price reaction to mandatory pension contributions and Campbell, Dhaliwal and Schwartz (2012) study its effect on companies' cost of capital.
} 
Brown (2013)). ${ }^{6}$ However, these papers do not address the fact that asset sales are endogenous firm decisions. I add to this literature by studying an exogenous shock to a firm’s ability to sell a particular type of assets (equity stakes), which provides for better identification.

\section{The German Tax Reduction Act of 2000 - Description and Event Study}

My main source of identification is the German Tax Reduction Act of 2000, which exempted the sale of equity stakes from corporate capital gains tax. Before the reform, many German companies held minority equity stakes in other unrelated companies. Also cross-holdings, where company A holds equity in company B while company B holds equity in company A, were not uncommon. This system of minority equity stakes and cross-holdings was often called Germany Inc. (Deutschland AG). Many of these equity stakes had been acquired in the distant past (often after the Second World War as a way to foster cooperation in the German economy (Edwards et al. (2004)). Thus, the equity stakes had book values significantly below their market values. Before the tax reform, corporate capital gains were taxed at 50 percent, which implied that companies would have suffered a significant tax burden if they had divested their equity stakes (Sautner and Villalonga (2010)). ${ }^{7}$

The German government lifted this lock-in by exempting the sale of equity stakes from capital gains taxes with the explicit intention to facilitate the break-up of Germany Inc. (Hoepner, 2000). This tax exemption was part of a wider tax reform, which included a reduction in individual and corporate tax rates as well as a change in dividend taxation. However, there is no reason to believe that the general tax changes had specific effects on firms with equity stakes. For a detailed description of the tax reform, see Keen (2002).

In Figure 1, I study how the announcement of the tax exemption affected the stock prices of companies holding equity stakes. While the general tax reform was announced on 21 December 1999, the plan for the corporate capital gains tax exemption was not confirmed until 23 December 1999. In Panel A, I plot the average returns for companies with and without minority equity stakes around these announcement dates. While there was no reaction to the announcement of the general tax reform, the announcement to exempt equity sales from corporate capital gains taxes had a large market impact. During a quiet stock market

\footnotetext{
${ }^{6}$ There is also a large literature that studies the announcement returns of asset sales and finds generally positive announcement returns (e.g. Alexander, Benson, and Kampmeyer (1984), Jain (1985), Klein (1986), Hite, Owers and Rogers (1987), Lang, Poulsen, and Stulz (1995), Borisova, John and Salotti (2011)).

${ }^{7}$ Capital gains were taxed at $40 \%$ corporate tax and trade tax that varies across regions, but was approximately $10 \%$. For more details see Edwards et al. (2004).
} 
environment, companies with equity stakes had an average stock return of 2.2 percent on the announcement date, while the return for companies without equity stakes was only 0.2 percent. The difference in the average returns between the two groups was larger than on any other day in the year around the announcement date.

In Panel B, I focus on firms holding large equity stakes, i.e. firms whose equity stakes made up at least 1 percent of their market value. I display the return difference between these firms and firms without equity stakes. Firms with large equity stakes experienced an excess return of 4.0 percent, by far the highest in the entire year around the event. These findings are consistent with the results of Edwards et al. (2004), who show a positive stock price reaction to the announcement of the tax reform concentrated in the six largest holders.

In Panel C, I split companies with large equity stakes into whether they are financial or non-financial companies. Given that banks held the largest equity stakes, we may be concerned that our results are driven exclusively by financial companies. While financial companies indeed have a larger announcement return of 5.1 percent, non-financial companies with large equity holdings also had a return of 2.4 percent, which is significant at the 5 percent level.

The event study shows that the corporate capital gains tax indeed constrained firms ability sell their equity stakes and that its abolition was not expected by the market. This idea is supported by the fact that Handelsblatt, Germany's leading business newspaper, headlined on the following day "Eichel [the finance minister] surprises stock market with a Christmas present". ${ }^{8}$ This surprise element is important, because it alleviates worries that acquisition decisions before 1999 are endogenous to the anticipation of the tax reform.

The German parliament passed the general tax reform in the summer of 2000 to be effective from 1 January 2001. The abolition of the capital gains tax did not come into effect until 1 January 2002. However, there were ways for companies to divest equity stakes before 2002 and still capture the better tax treatment. For example, Deutsche Bank sold a stake in Allianz on 6 June 2000 and stated in its investor relations release:

"The economic disposal has been achieved by an innovative structure which allows Deutsche Bank to obtain the full benefits from the upcoming tax reform in Germany. The transaction will qualify as a disposal for the Deutsche Bank Group in its IAS accounts, giving

\footnotetext{
8 “Eichel überrascht die Börse mit einem Weihnachtsgeschenk”, Handelsblatt, December 24, 1999.
} 
rise to a capital gain in excess of EUR 2 billion, but without triggering a tax disposal in the current year." 9

Furthermore, anticipating the tax reform, companies may have chosen to reduce their cash buffer and thereby use the additional financial resources already before they actually sold any equity stakes. Accordingly, I use the announcement of the tax reform in December 1999 as the event date.

On the other hand, when the tax reform took effect in 2002, stock prices in Germany had experienced a recent bear market and firms may have been reluctant to sell their equity stakes quickly. Therefore, I examine a relatively long post-event period until 2007. To make the event window symmetric, I use 1992-1999 as the pre-event period. However, I show in Table 12 that our results are robust to a shorter event window.

I am not the first to use the German capital gains tax as a natural experiment. As mentioned above, Edwards et al. (2004) study the stock market reaction to the tax reform. Weber (2009) studies the change of ownership concentration after the tax reform and finds that ownership concentration has been reduced. This finding is consistent with firms selling their equity stakes in other companies. Sautner and Villalonga (2010) use the tax reform as an exogenous shock to firms' ownership structures. They find that firms whose ownership concentration increases reduce diversification and exhibit an increase in the efficiency of internal capital markets. Von Beschwitz and Foos (2014) study how the divestiture of bank's equity stake after the tax reform affect the lending relationship.

\section{Data and Variable Construction}

\subsection{Sample construction}

The data used in this study comes from five different databases. I obtain ownership data from Who owns Whom? (Wer gehört zu wem?) provided by Picoware as of July 1999. This database contains roughly 18,000 private as well as publicly traded firms and their owners. The data is based on public sources such as balance sheets and additional self-reported information by companies. I obtain data on acquisitions from Thompson Reuter's SDC Platinum. I use Worldscope for balance sheet data and Datastream for stock market data. In addition, I use

\footnotetext{
9 "Deutsche Bank reduces Allianz stake to 4.1\%" (https://www.db.com/ir/en/content/ir_releases_2000_3464.htm) and "Deutsche plays clever in Allianz sale to avoid CGT" (http://www.efinancialnews.com/story/2000-06-12/deutsche-playsclever-in-allianz-sale-to-avoid-cgt?ea9c8a2de0ee111045601ab04d673622).
} 
balance sheet and stock market data from Compustat Global if observations are missing in Worldscope or Datastream.

I limit my sample to publicly listed companies to be able to compute announcement returns. I define Equity Stake 1999 as an indicator variable equal to one if the firm owns a minority equity stake in another (public or private) company before the tax reform. I include direct ownership as well as indirect ownership through subsidiaries (see Appendix 2 for more details). Following Edwards et al. (2004), I define a minority equity stake to be any equity stake in another company below 20 percent. Thus, I assume that equity stakes below 20 percent are less likely to generate economic benefits and are more likely to be divested after the tax reform. In my sample, there are 554 companies from the Who owns Whom? database that I can match to Worldscope or Compustat Global. Of these companies, 130 companies (23.4 percent) own at least one equity stake.

I study acquisitions of both public and private targets. However, to exclude the acquisition of subsidiaries as well as investments without economic control, I focus on acquisitions, in which the acquirer owns less than 25 percent of shares before the acquisition and more than 50 percent after the acquisition. If several acquisitions are announced on the same day, this day only enters the regressions once. Variable definitions are in Appendix 1. More detail on sample and variable construction is in Appendix 2.

\subsection{Summary statistics}

In Figure 2, I display the companies in my sample by 10 Fama French industries. Companies with equity stakes in 1999 cover all industries except oil \& gas, but are somewhat overrepresented in the utilities and financial sectors, while they are underrepresented in manufacturing, non-durables and business equipment. I ensure that the different industry composition is not driving my results by controlling for industry specific trends with industryyear fixed effects (Gormley and Matsa (2014)). Also it should be noted that firms with equity stakes are not concentrated in the IT sector, which alleviates concerns that our results may be driven by the burst of the internet bubble.

Panel A of Table 2 displays the summary statistics of companies with and without equity stakes in 1999 before the tax reform (December 1999). I display median and mean values and test whether the difference in the two subsamples is statistically significant. In terms of investment opportunities measured as Tobin's Q, there is no difference between companies with and without equity stakes. The firms in the two subsamples are also similar in terms of 
leverage, dividend ratio and return on assets. The main difference is that companies with equity stakes are considerably larger as measured by market capitalization. I address this difference by including firm size interacted with the post reform dummy in my difference-in-difference set-up. In addition, I run regressions on a sample matched by industry and firm size.

Panel B displays more details on the subsample of firms with equity stakes in 1999. In this subsample, the median firm holds 2 equity stakes, but the mean is 4.9 as some firms own a large number of equity stakes. Next, I display the (pre-tax) value of the equity stakes. Given that I include equity stakes in private companies, this value is only an estimate (see Appendix 2 for details of the estimation). The distribution of the value of equity stakes is highly skewed. The median company holds equity stakes worth EUR 7.4 million, while the mean is EUR 646 million. Next, I compare these values to the firm's own marked capitalization. On average, the equity holdings account for 24 percent of a firm's market capitalization (median 0.73 percent). I use the fact of this skewed distribution by showing that my results are stronger in the subsample with the largest equity holdings.

Panel C displays summary statistics on the acquisition level. The average acquisition has a positive announcement return of 0.59 percent (median 0.24 percent). 35 percent of acquisitions are diversifying in the sense that the target is in another industry (using 10 Fama French industry groups). 59 percent of targets are outside Germany, 55 percent are publicly listed and 53 percent are independent firms, while 47 percent are spin-offs. SDC Platinum only provides the payment information in 26 percent of the cases, but for these cases, 86 percent of the acquisitions are paid in cash.

\section{Results}

\subsection{Divestitures of equity stakes following the tax reform}

Several prior studies find that companies divested a large part of their equity stakes following the tax reform (Kengelbach and Roos (2006), Höpner and Krempel (2006)). In Table 3, I confirm this result for my dataset. I use Who owns Whom? data from November 2006 to determine which equity stakes have been divested. I check by hand that equity stakes have indeed been divested and not just moved to a different holding vehicle. For the stakes for which I have data, 61.1 percent are divested by November 2006. This means that 83 percent of companies sold at least one equity stake until November 2006.

It is not surprising that many firms sold their equity stakes as they had strong incentives to do so: First and most importantly, if the company is unrelated, then holding an equity stake in 
it will not create value and the locked-in capital can be put to a more effective use. Second, companies realized large accounting gains by selling the equity stakes, which was an incentive to sell for managers, who cared about reporting a high accrual income. Third, there was a general election in Germany in September 2002, and the political opposition had announced a plan to reintroduce capital gains taxation. The opposition narrowly lost the election and the sale of equity stakes is tax free for companies to this day. However, in 2002 the opposition was ahead in the polls, which caused some companies to sell their equity stakes to front-run a return of the tax (Pauly and Schäfer (2002)).

\subsection{Acquisition probability}

In this section, I study how a company's acquisition behavior depends on its financial resources using the German capital gains tax reform as identification. The tax reform enabled firms to sell their equity stakes tax free. Thus, it provided a cash windfall only for companies able to sell an equity stake. Accordingly, I compare how the acquisition behavior of companies with equity stakes in 1999 changes relative to companies without equity stakes.

I condition my analysis only on ownership of equity stake before the tax reform rather than divestiture of equity stakes because the decision of whether or not to sell the equity stake is endogenous. This methodology follows Frydman and Hilt (2010) and is essentially a reduced form instrumental variable approach, in which the sale of an equity stake is instrumented with the existence of an equity stake prior to the tax reform. As we have seen above, most companies did indeed divest at least some of their equity stakes.

Under the null hypothesis of no financial constraints, a cash windfall should have no effect on the acquisition activity, since companies without a cash windfall could simply raise the same amount of money in the financial market. On the other hand, under both the financial constraints theory and the free cash flow theory, a cash windfall should result in more acquisitions. This prediction implies that it is easier to raise financing by selling equity stakes than by issuing equity or bonds. This assumption seems reasonable given that divestitures of equity stakes are less affected by asymmetric information (Edmans and Mann (2013)).

I start with a univariate analysis in Figure 3. I examine the probability that a company undertakes an acquisition in a certain year calculated as the number of companies doing an acquisition divided by the total number of companies. After the tax reform, companies that owned an equity stake in 1999 experience an increase in acquisition probability of 7.4 percentage points or 18.7 percent relative to the pre-event period. At the same time, the 
probability of undertaking an acquisition slightly decreases by 1.2 percentage points for companies without equity stakes. These results suggest that the additional financial resources from selling their equity stakes led companies with equity stakes to increase their acquisition activity after the tax reform.

After illustrating the overall economic effect above, I now undertake a more detailed analysis using a difference-in-difference set-up:

Acquisition Probability ${ }_{f, t}=\alpha_{f}+\alpha_{t}+\beta *$ Equity Stake $1999_{f} *$ Post Reform $+\varepsilon_{f, t}$

Where Equity Stake 1999 is a dummy variable equal to one if the company holds a minority stake in 1999 and Post Reform is a dummy variable equal to one after the announcement of the tax reform; and $\alpha_{f}, \alpha_{t}$ denote firm and year fixed effects (which also absorb the constitutive terms of the interaction Equity Stake 1999 and Post Reform). The year fixed effects absorb any time trends. For example, the tax reform may make acquisitions more attractive, since future divestitures are not subject to capital gains taxation. However, this effect should be the same for companies with and without equity stakes and thus be captured by the year fixed effects. The fundamental identifying assumption of this analysis is that factors other than the capital gains tax reform affect companies with and without equity stakes in the same way (parallel trends assumption). Since there might be different trends by industry, I add industry-year fixed effects. I do not include time-varying controls as these may be endogenously affected by the tax reform. However, I add firm specific controls (measured in 1999) interacted with the post reform dummy. This is a common method to account for differing trends depending on industry characteristics and has been used in many difference-in-difference studies, for example Barrot (2015). The final regression set-up is:

$$
Y_{t, f}=\alpha_{f}+\alpha_{t}+\alpha_{i, t}+\beta * \text { Equity Stake } 1999_{f} * \text { Post Reform }+\gamma * \text { Controls }_{f} * \text { Post Reform }+\varepsilon_{f, t}
$$

Where $\alpha_{i, t}$ are industry-year fixed effects and Controls $_{f}$ is a vector with size, Tobin's Q and leverage as of December 1999. I cluster standard errors at the firm level, which controls for the serial correlation issue in difference-in-difference analyses (Betrand, Duflo, and Mullainathan (2002)).

The results are reported in Table 4 . The dependent variable is a dummy variable equal to one if a company undertakes an acquisition in a certain year. I follow Harford (1999) and study the probability of undertaking an acquisition in a given year rather than the number of acquisitions, since several small acquisitions could be equivalent to one large acquisition. Due 
to the incidental parameters problem (Chamberlain (1980)), I run logit estimation conditional on firms rather than logit with firm fixed effects. In addition, I also run a linear probability model estimated with OLS.

In all specifications, the interaction of Equity Stake 1999 and Post Reform has a positive effect on the acquisition probability. In non-linear difference-in-difference set-ups such as logit models, only the sign of the interaction coefficient can be interpreted (Puhani (2012), Ai and Norton (2003)). Thus, I refer the reader to the univariate analysis above to get an impression of the economic magnitude of the effect. The linear probability model (OLS estimation) estimates a relative increase of the acquisition probability of 8 percentage points. This result is statistically significant at the 5 percent level for all specifications. It is consistent with companies using the additional cash from liquidating their equity stakes to engage in additional acquisitions.

To get a better impression of the exact timing of the increase in acquisitions, I follow Gormley and Matsa (2011) and plot the point estimates of a modified version of Regression 1 in Figure 4. In this modified regression set-up, I allow the effect of owning an equity stake in 1999 to vary by year from 6 years before to 8 years after the announcement of the tax reform. Before the tax reform, there is no apparent trend in the difference between firms with and without equity stakes, thus validating the parallel trend assumption. If anything, there seems to be a slight downwards trend in the relative acquisition probability of firms with equity stakes. After the announcement of the tax reform in 1999, we see a reversal in the trend and an increase in the number of acquisitions for companies with an equity stake in 1999. Especially, after the law comes into effect in January 2002 and companies can sell their equity stakes tax-free, we see a large increase in the number of acquisitions of these companies. This suggests that the additional acquisitions were indeed caused by the tax windfalls following the reform.

Overall, the results suggest that companies experiencing a cash windfall engage in more acquisitions. This finding is not consistent with the perfect capital market assumption of Modigliani and Miller (1958). So far, these results do not tell us whether the additional acquisitions represent overinvestment (free cash flow theory) or a reduction in underinvestment (financial constraints theory). I will address this question in the following section.

\subsection{Announcement returns}

After considering the number of acquisitions, I now examine whether these acquisitions are value increasing. I proxy for the profitability of the acquisitions using announcement returns. This assumes that the market did not fully anticipate the acquisition decision before the 
announcement and thus the stock return represents the change in firm value resulting from the acquisition. This assumption is standard to any analysis of acquisition announcement returns (e.g. Masulis, Wang and Xie (2007), Moeller, Schlingemann and Stulz (2005)).

I start with a univariate analysis in Figure 5. As is common in the literature, I define Announcement Return as the acquirer return in the 3 trading days (t-1 to t+1) around the announcement date of the acquisition reported in SDC Platinum. In Panel A, I focus on raw returns. I study one-factor alphas in Panel B and four-factor alphas in Panel C. I use factors specifically constructed for the German market (see Appendix 2). After the tax reform, companies with an equity stake in 1999 experience a decrease in the average acquisition announcement return by 0.6 percent ( 0.4 percent in four-factor alpha). In the same time, the average announcement alpha slightly increases for companies without equity stakes. This finding suggests a reduction in average announcement returns for companies that received a cash windfall. We will now study whether this result transfers to a more rigorous analysis.

Table 5 reports the results of a difference-in-difference specification examining the change in acquirer announcement returns before and after 1 January 2000. The unit of observation is an acquisition. As above, I control for size, leverage and Tobin's Q interacted with the post reform dummy as well as firm and industry-year fixed effects. I add the return in the past year (t-365 to t-20) to control for the momentum effect as reported by Jegadeesh and Titman (1993).

There are advantages and disadvantages to controlling for merger characteristics such as payment methods and the type of target. On the one hand, merger characteristics can clearly be endogenous to the cash windfall and thus controlling for them could distort the analysis. For example, it is perceivable that firms receiving a cash windfall pay more in cash or expand more abroad. On the other hand, merger characteristics have been clearly related to announcement returns and it is standard to control for them. Therefore, I report regression results with and without these controls. The regressions without merger-specific controls show the total effect of cash windfalls on announcement returns including the differences coming from different merger characteristics. While the other regression set-up shows the effect conditional on these (endogenous) variables.

The merger characteristics that I control for include Cash Acquisition, an indicator variable, which is equal to one if the consideration listed in SDC Platinum is entirely paid using cash, capital infusion or debt reduction. Because the data item on considerations is often missing in SDC Platinum, I employ another indicator variable equal to one if I do not know the method of 
payment (in this case, Cash Acquisition is set to 0). I also have dummy variables for diversifying acquisitions (different 10 Fama French industry of the target), cross-border deals, publicly listed targets and targets which are independent companies rather than spin-offs sold by another company.

Robust to all these controls and fixed effects, companies that own equity stakes in 1999 experience a significant decrease in announcement returns after the tax reform. The effect is also economically significant. Companies receiving a cash windfall experience a decrease in announcement returns by roughly 1.2 percentage points. For one- and four-factor announcement alphas, the effect is approximately 1 percentage point. Interestingly, controlling for the deal characteristics does not change the result. This suggests that the difference comes not so much from acquiring different targets as from selecting worse targets and from overpaying, which is consistent with the free cash flow theory.

To get a better impression of the exact timing of the decrease in announcement returns, I once again plot the coefficients from a panel regression in which I interact Equity Stake 1999 with year dummy variables from 1994 to 2007. The point estimates of this regression are presented in Figure 6. Before the tax reform, there is somewhat of an upward trend in announcement returns for firms with equity stakes. After the announcement of the tax reform in 1999, we see a clear drop in the average announcement returns of firms with equity stakes. We observe a further drop after the law comes into effect in January 2002. This suggests that the decrease in average announcement returns was indeed caused by the tax windfalls following the tax reform.

\subsection{Interpretation of results}

Our results indicate a clear reduction in average announcement returns for firms with a cash windfall. However, such a decrease does not necessarily mean that firm value is destroyed. Because average announcement returns of firms with cash windfalls remain positive after the tax reform (see Figure 5), the decrease might be explained by decreasing but still positive marginal returns to scale. To illustrate this argument, consider an example with two acquisition opportunities with net present values (NPV) of 2 and 1. If the firm is financially constrained and can take only one project, its average NPV is 2 . If it becomes unconstrained and takes both projects, the average NPV decreases to 1.5 .

However, a simple calculation reveals that the decrease in average announcement returns from 0.65 percent to 0.05 percent is too large to be explained by decreasing (but positive) 
marginal returns. Even assuming all additional acquisitions have expected announcement returns of zero, the number of acquisitions would have to increase by 1200 percent to drive the average return down to 0.05 percent (as $(0.65+12 * 0) / 13=0.05)$. Yet, we observe an increase of only 19 percent. Thus, the strong decrease in average announcement returns rejects non-agency theories of financial constraints and supports the free cash flow theory. ${ }^{10}$

\subsection{Yearly sum of announcement returns}

It is possible to confirm the simple calculation above using a regression framework. To do this, I study the combined profitability of all acquisitions of a company (following Bertrand and Mullainathan (2005)). Since only positive net present value (NPV) projects are taken under the financial constraints theory, every additional acquisition should increase the sum of announcement returns. Consider the above example with two acquisition opportunities with NPVs of 2 and 1. If the firm is financially constrained and can take only one project, its average NPV is 2 and the sum of NPVs is 2. If it becomes unconstrained, the average NPV decreases to 1.5 due to decreasing marginal returns, but the sum of NPVs increases to 3. However, under the free cash flow theory additional investments are value destroying and will decrease the sum of announcement returns.

Therefore, I estimate difference-in-difference regressions where the dependent variable is the sum of the announcement returns of all acquisitions a company undertakes within a year. If the additional cash allows managers to engage in additional value increasing acquisitions, we expect an increase in the Sum of Announcement Returns, while we expect a decrease under the free cash flow theory.

Table 6 displays the results of this analysis. Companies that receive a positive cash shock see a decrease in aggregate yearly announcement returns of 0.6 percent. In Regressions 2 and 3, I show that the effect is also significant for sums of one and four-factor alphas at similar magnitudes. These results imply that the additional acquisitions not only have lower, but actually negative announcement returns and therefore destroy value. The result is also economically significant. It implies that approximately 0.6 percent of firm value is destroyed every year by additional acquisitions or worse execution of acquisitions. Over my sample period, this effect accumulates to 4.8 percent.

\footnotetext{
${ }^{10}$ This argument assumes that investment opportunities are the same before and after the tax reform. This assumption seems plausible, given that average announcement returns stayed roughly constant for the control group.
} 


\subsection{Differential effect by the size of the cash windfall}

Firms with larger equity stakes in terms of total market capitalization receive a larger cash windfall from divesting. Thus, we might expect a stronger effect for these firms. To test this idea, I repeat the analyses from Tables 4 to 6, but split the treated group along the median in terms of the size of equity stakes as a fraction of the holder's market capitalization. I introduce two new dummy variables: Large Equity Stake 1999 is equal to one if the company ranks above the median by aggregate value of equity holdings as a share of its market capitalization, while Small Equity Stake 1999 equals one if it ranks below the median. If a company has no equity stakes, both variables are set to 0. By including both of these variables (interacted with Post Reform) in the regression, I estimate the effect of a large windfall and a small windfall both compared to the control group of firms without equity stakes.

The results are reported in Table 7. In Panel A, I repeat the analysis of Table 4 on acquisition probability. Firms receiving a large cash windfall see an 11 percentage point increase in acquisition probability, which is statistically significant at the 1 percent level. On the other hand, firms with a small cash windfall see a lower increase of 5 percentage points, which is not statistically significant. This suggests that a small cash windfall is not enough to trigger a significant increase in the number of acquisitions, but that a large cash windfall is.

In Panel B, the dependent variables are announcement returns and announcement alphas thus mirroring the analyses of Table 5. Firms receiving a large cash windfall see a large drop in average announcement returns of about 2 percent that is significant at the 1 percent level. On the other hand, firms with a small cash windfall see a lower decrease of 0.9 percent, which is not statistically significant. The result for yearly sum of announcement returns (Panel C) is similar: A large cash windfall leads to a decrease in yearly sum of announcement returns of 0.8 percentage points, significant at the 10 percent level, while a small cash windfall only leads to an insignificant decrease of approximately 0.4 percentage points. These findings show that the effect on the firms' acquisition behavior depends on the size of the cash windfall, which is consistent with the free cash flow theory.

\subsection{Differential effect by whether equity stakes have been sold}

In this section, I study whether there are larger results for firms that sold a larger fraction of their equity stakes. Using the data from Table 3, I compute the fraction of equity stakes a firm sold as the EUR value of equity stakes sold divided by the total EUR value of equity stakes. Thus, implicitly I assume that equity stakes with missing data have not been sold. 
I use the same set-up as in the previous section. I define Many Equity Stakes Sold as a dummy variable equal to 1 if a firm ranks above the median in terms of fraction of equity stakes sold, while Few Equity Stakes Sold is equal to 1 if a firm ranks below the median. If a company has no equity stakes, both variables are set to 0 . By including both of these variables (interacted with Post Reform) in the regression, I estimate the effect of having equity stakes that were mainly sold and having equity stakes that were mainly kept both compared to the control group of firms without equity stakes.

Table 8 displays the results. In Panel A, I repeat the analysis of Table 4 on acquisition probability. Firms that mainly sold their equity stakes see a 10 percentage point increase in acquisition probability, which is statistically significant at the 1 percent level. On the other hand, firms that sold few equity stakes see a lower increase of 5 percentage points, which is not statistically significant.

Similarly, the effect on announcement returns is larger for firms divesting a larger fraction of their equity stakes. Firms that mainly sold their equity stakes see a large drop in average announcement returns of about 1.5 percent, while firms that mainly kept their stakes see a lower decrease of 1 percent. The result for yearly sum of announcement returns (Panel C) is similar: Firms that sold many equity stakes experience a decrease in yearly sum of announcement returns of 0.8 percentage points, vs. approximately 0.4 percentage points for firms that sold few.

These results are consistent with a larger effect on acquisition activity if stakes are actually divested, thereby supporting the previous findings in line with the free cash flow theory. However, these effects might also be driven by endogeneity concerns. For example, a firm might sell an equity stake in order to finance an acquisitions (reverse causality). Indeed, throughout the paper, I always condition on ownership rather than sales of equity stakes to avoid such endogeneity issues. While potentially driven by endogeneity concerns, it is still comforting to see that the result goes in the right direction.

\subsection{Capital expenditures}

One might be concerned that the increase in acquisition activity is offset by a decrease in capital expenditures, i.e. that acquisitions act as a substitute for internal growth. Therefore, I now study how capital expenditures change for companies with equity stakes relative to companies without equity stakes after the tax reform. I run the same regression set-up as in Table 4, but using capital expenditures over assets as the dependent variable. 
My sample contains both financial and non-financial companies. However, capital expenditures is an odd measure for investments of financial companies. Normally, the measure of choice for the expansion of banks is the amount of loans issued. On the other hand, high capital expenditures are also a sign of expanding businesses (e.g. new offices) or of consuming perquisites (e.g. more representative headquarters). Therefore, I run the regressions for the full sample as well as for the subsample of non-financial companies.

Table 9 depicts the results of this analysis. On the full sample, there is a positive effect on capital expenditures of around 1 percent of assets. The effect is significant at the 5 percent level. However, if I exclude financial companies in regressions 3 and 4, the effects is smaller and not statistically significant anymore. However, it is still a sizeable 0.7 percent of assets per year, which amounts to 5.6 percent of assets over the whole sample period and represents an increase of 13 percent relative to the sample median. This finding suggests, that firms with cash windfalls increased their capital expenditures at least somewhat and certainly shows that acquisitions are not merely a replacement for lower capital expenditures.

\subsection{Dividends}

In perfect capital markets, managers that maximize shareholder value should pay out a cash windfall to the company's shareholders. Therefore, I study how dividends as a fraction of assets changed following the tax reform. I use the same regression set-up as above. The results are displayed in Table 10. There is virtually no increase in dividends, with all regression coefficients being insignificant and around 0.1 percent. This result suggests that almost no part of the cash windfalls is paid out to shareholders via dividends, consistent with the free cash flow theory.

\section{Robustness Checks}

\subsection{Matched sample}

The companies holding equity stakes in 1999 are larger than the sample average and not evenly distributed among industries. As a further step to address concerns about the violation of the parallel trend assumption, I rerun my main tests using a matched control-sample. For each company with an equity stake in 1999, I select the company within the same 10 Fama-French industry that is closest by log market capitalization in 1999. I ensure that the same company does not enter the regression twice. If two companies have the same best match, the second best match is chosen instead. 
Table 11 displays the results of this analysis. In Panel A, I re-estimate the effect of cash windfalls on acquisition activity. Using the matched sample I find very similar results of an increase in acquisitions probability of 7.4 percent in the linear probability model. Thus, the matched sample analysis suggests that the baseline regression already accounts well enough for differences in characteristics between firms with and without equity stakes in 1999. In Panel B, I re-estimate the effect of cash windfalls on the average announcement return. Here, the matching approach actually increases the results to 1.6 percentage points (1.2 in terms of alpha). This suggests that the main regressions might underestimate the effect. In Panel C, I study the effect on the Sum of Announcement Returns replicating regressions from Table 6. I find a negative effect of 0.9 percentage points ( 0.8 in terms of alpha) which is an increase relative to the regressions in Table 6. All effects are also statistically significant. Overall, the matched sample approach yields results consistent with the main regressions. For the most specifications the reported effects actually increase in economic magnitude. This suggests that the differences in industry and size composition in the treated and control sample do not cause the effects reported in the main specification.

\subsection{Shorter sample period}

Throughout the paper, I use a relatively long sample period from 1992 to 2007 to account for a potential delayed reaction to the tax reform. A delayed reaction is likely, because the tax reform - while announced in December 1999 - did not take effect until 2002. At that time, the German stock market was experiencing a bear market, which might have led some firms to postpone the sale of equity stakes further.

However, I show that the results are robust to using a shorter sample period from 1996 to 2005. Table 12 displays the results. For acquisition probability, the results are almost identical. For announcement returns, they are close to identical in terms of coefficients, but due to the lower number of observations they are not statistically significant. For yearly sum of announcement returns the results are even larger over the shorter period (1.2 percentage points vs. 0.6 percentage points). This analysis suggests that our results are robust to using a shorter sample period. This finding is not very surprising, given that Figures 4 and 6 suggest that most of the impact of the tax reform happened in the years after its announcement from 2000 to 2002.

\subsection{Controlling for Reverse Equity Stakes}

When a firm sells an equity stake in another firm, there are two effects: The selling firm receives extra cash and the firm whose equity is sold experiences a change in its ownership, which may 
affect its corporate governance. I focus on the first effect in this paper, while the effect of the ownership change is examined in Sautner and Villalonga (2010). In this section, I address the concern that the ownership effect may be driving our results as well. In general, it seems unlikely that ownership changes caused by the tax reform drive our results, because both the treated and the control group should be affected. However, given that cross-holdings were relatively common in Germany, it may be possible that firms owning equity stakes are also more likely to be owned via an equity stake. If this is the case, ownership changes might bias our results.

To address this concern, I rerun our main analysis, but include as an additional control the variable Reverse Equity Stake 1999 (interacted with Post Reform). Reverse Equity Stake 1999 is a dummy variable equal to one if at least one publicly listed German firm owns an equity stake below 20\% in the company in December 1999. Thus the definition is the same as for Equity Stake 1999, but in the opposite direction, i.e. it is equal to one if the firm is owned via an equity stake rather than if it owns an equity stake. I base this variable on ownership of firms that are German and publicly listed for two reasons: First, to ensure that it is the exact counterpart to Equity Stake 1999 and second, because the tax reform only applied to German firms and private firms are likely to be holding companies of private owners, which are less likely to sell after the tax reform.

The result of this robustness check are presented in Table 13. Including the new control variable does not change the results much. The result for acquisition probability is actually large, while the effect on announcement returns is unchanged. This finding confirms that our results are indeed caused by the cash windfalls rather than being spuriously related to governance changes.

\subsection{Placebo test}

In difference-in-difference analyses, it is common to confirm the parallel trend assumption using a placebo test. I conduct a placebo test by assuming the tax reform would have taken place in December 1994. I use 1990-1994 as the pre-event period and 1995-1999 as the post event period. I use the same classifications of a company owning an equity stake as above, i.e. December 1999. I also take the control variables to be as of 1999 to have everything else besides the event timing comparable to my main analysis. However, the results do not materially change when I instead use control variables as of December 1994. 
The results are reported in Table 14. First, I repeat the analysis on acquisition probability. As one would expect, the results are not statistically significant and generally close to zero. Then, I repeat the analyses on announcement returns. Here the results are insignificant as well and point into the opposite direction of our main specification. Overall, the placebo test confirms that our results are not driven by mechanical relationships or violations of the parallel trend assumption.

\section{Conclusion}

In this paper, I study cash windfalls resulting from the German capital gains tax reform in 2000. Before the reform, many German companies held minority equity stakes in other unrelated firms. These equity stakes often had high market values, making up a sizeable part of the holder's assets. The capital gains tax of 50 percent prevented companies from selling their equity stakes even if there was no economic reason to hold on to them. The tax reform completely abolished the capital gains tax, allowing companies to sell their stakes and cash in their capital gains.

Because the tax reform only affected companies that owned equity stakes, I can use difference-in-difference estimation to examine the effect of this cash windfall on firms' acquisition and investment activity. I find that companies able to sell an equity stake after the tax reform, engage in more acquisitions and that these acquisitions are value destroying. The effects are stronger if the market value of the equity stakes and thus the cash windfall is larger. I also find some increase in capital expenditures, but no effect on dividends. Overall, my results suggest that the cash windfalls which result from the divestitures of the equity stakes of Germany Inc. were used to engage in empire building through acquisitions. This behavior is consistent with the free cash flow theory and shows how the ability to engage in assets sales can affect investment. 


\section{References}

Ai, Chunrong, and Edward C. Norton, 2003, Interaction terms in logit and probit models, Economics Letters 80, 123-129.

Alexander, Gordon J., P. George Benson, and Joan M. Kampmeyer, 1984, Journal of Finance 39, 503-517.

Almeida, Heitor, Murillo Campello, Bruno Laranjeira, and Scott Weisbenner, 2009, Corporate Debt Maturity and the Real Effects of the 2007 Credit Crisis, NBER Working Paper No. 14990.

Almeida, Heitor, Murillo Campello, and Michael S. Weisbach, 2004, The Cash Flow Sensitivity of Cash, The Journal of Finance 59, 1777-1804.

Almeida, Heitor, and Murillo Campello, 2007, Financial Constraints, Asset Tangibility, and Corporate Investment, Review of Financial Studies 20, 1429-1460.

Alti, Aydoḡan, 2003, How Sensitive Is Investment to Cash Flow When Financing Is Frictionless? The Journal of Finance 58, 707-722.

Bakke, Tor-Erik, and Toni M. Whited, 2012, Threshold Events and Identification: A Study of Cash Shortfalls, Journal of Finance 67, 1083-1111.

Barrot, Jean-Noël, 2015, Trade Credit and Industry Dynamics: Evidence from Trucking Firms, Journal of Finance, forthcoming.

Bates, Thomas W., 2006, Asset Sales, Investment Opportunities, and the Use of Proceeds. Journal of Finance 60, 105-135.

Bates, Thomas W., Kathleen M. Kahle, and René M. Stulz, 2009, Why Do U.S. Firms Hold So Much More Cash than They Used To? The Journal of Finance 64, 1985-2021.

Baumol, William J., 1959, Business Behavior, Value and Growth. New York: Macmillan .

Bertrand, Marianne, and Sendhil Mullainathan, 2005, Profitable Investments or Dissipated Cash? Evidence on the Investment-Cash Flow Relationship From Oil and Gas Lease Bidding, National Bureau of Economic Research Working Paper Series 11126.

Blanchard, Olivier J., Florencio Lopez-de-Silanes, and Andrei Shleifer, 1994, What do firms do with cash windfalls? Journal of Financial Economics 36, 337-360.

Borisova, Ginka and James R. Brown, 2012, R\&D Sensitivity to Asset Sales Proceeds: New Evidence on Financing Constraints and Intangible Investment, Journal of Banking and Finance 37, 159-173.

Borisova, Ginka, Kose John, and Valentina Salotti, 2011, Cross-Border Asset Sales: Shareholder Returns and Liquidity, Working Paper.

Campbell, John L., Dan S. Dhaliwal, and William C. Schwartz, 2012, Financing Constraints and the Cost of Capital: Evidence from the Funding of Corporate Pension Plans, Review of Financial Studies 25, 868-912.

Carhart, Mark M., 1997, On Persistence in Mutual Fund Performance, The Journal of Finance 52, 57-82.

Chamberlain, Gary, 1980, Analysis of Covariance with Qualitative Data, The Review of Economic Studies 47, pp. 225-238.

Chaney, Thomas, David A. Sraer, and David Thesmar, 2009, The Collateral Channel: How Real Estate Shocks Affect Corporate Investment, Working Paper. 
Denis, David J., and Valeriy Sibilkov, 2010, Financial Constraints, Investment, and the Value of Cash Holdings, Review of Financial Studies 23, 247-269.

Dharmapala Dhammika, Fritz C. Foley, and Kristin J. Forbes, 2011, Watch What I Do, Not What I Say: The Unintended Consequences of the Homeland Investment Act. Journal of Finance 66, 753-87.

Dittmar, Amy, Jan Mahrt-Smith, and Henri Servaes, 2003, International Corporate Governance and Corporate Cash Holdings, Journal of Financial and Quantitative Analysis 38, 111.

Dittmar, Amy, and Jan Mahrt-Smith, 2007, Corporate governance and the value of cash holdings, Journal of Financial Economics 83, 599-634.

Edmans, Alex, and William Mann, 2013, Financing Through Asset Sales, Working Paper.

Edwards, Courtney H., Mark H. Lang, Edward L. Maydew, and Douglas A. Shackelford, 2004, Germany's Repeal of the Corporate Capital Gains Tax: The Equity Market Response. The Journal of the American Taxation Association 26(supplement), 73-97.

Erickson, Timothy and Toni M. Whited, 2000, Measurement Error and the Relationship between Investment and q, Journal of Political Economy 108, pp. 1027-1057.

Faccio, Mara, John J. McConnell, and David Stolin, 2006, Returns to Acquirers of Listed and Unlisted Targets, Journal of Financial and Quantitative Analysis 41, 197.

Faulkender, Michael, and Rong Wang, 2006, Corporate Financial Policy and the Value of Cash, The Journal of Finance 61, 1957-1990.

Faulkender, Michael, and Mitchell Petersen, 2012, Investment and Capital Constraints: Repatriations Under the American Jobs Creation Act, Review of Financial Studies 25, 33513388.

Fazzari, Steven M., R. G. Hubbard, and Bruce C. Petersen, 2000, Investment-Cash Flow Sensitivities are Useful: a Comment on Kaplan and Zingales, Quarterly Journal of Economics 115, 695-705.

Fazzari, Steven M., R. G. Hubbard, Bruce C. Petersen, Alan S. Blinder, and James M. Poterba, 1988, Financing Constraints and Corporate Investment, Brookings Papers on Economic Activity 1988, pp. 141-206.

Franzoni, Francesco, 2009, Underinvestment vs. overinvestment: Evidence from price reactions to pension contributions, Journal of Financial Economics 92, 491-518.

Frésard, Laurent, and Carolina Salva, 2010, The value of excess cash and corporate governance: Evidence from US cross-listings, Journal of Financial Economics 98, 359-384.

Frydman, Carola, and Eric Hilt, 2010, Predators or Watchdogs? Bankers on Corporate Boards in the Age of Finance Capitalism, Working Paper .

Gan, Jie, 2007, Collateral, debt capacity, and corporate investment: Evidence from a natural experiment, Journal of Financial Economics 85, 709-734.

Glaser, Markus, Florencio Lopez-de-Silanes, and Zacharias Sautner, 2013, Opening the Black Box: Internal Capital Markets and Managerial Power, Journal of Finance 68, 1577-1631.

Gomes, Joao F., 2001, Financing Investment, The American Economic Review 91, pp. 12631285.

Gormley, Todd A., and David A. Matsa, 2014, Common Errors: How to (and Not to) Control for Unobserved Heterogeneity, Review of Financial Studies 27, 617-661. 
Gormley, Todd A., and David A. Matsa, 2011, Growing Out of Trouble? Corporate Responses to Liability Risk, Review of Financial Studies 24, 2781-2821.

Harford, Jarrad, Sattar A. Mansi, and William F. Maxwell, 2008, Corporate governance and firm cash holdings in the US, Journal of Financial Economics 87, 535-555.

Harford, Jarrad, 1999, Corporate Cash Reserves and Acquisitions, The Journal of Finance 54, 1969-1997.

Hite, Gailen L., James E. Owers and Ronald C. Rogers, 1987, The Market for Interfirm Asset Sales: Partial Sell-Offs and Total Liquidations, Journal of Financial Economics 18, 229-252.

Höpner, Martin, 2000, Unternehmensverflechtung im Zwielicht: Hans Eichels Plan zur Auflösung der Deutschland AG, Working Paper.

Höpner, Martin, and Lothar Krempel, 2006, Ein Netzwerk in Auflösung: Wie die Deutschland AG zerällt, Max Planck Institute for the Study of Societies .

Hoshi, Takeo, Anil Kashyap, and David Scharfstein, 1990, The role of banks in reducing the costs of financial distress in Japan, Journal of Financial Economics 27, 67-88.

Hovakimian, Gayane, and Sheridan Titman, 2006, Corporate Investment with Financial Constraints: Sensitivity of Investment to Funds from Voluntary Asset Sales, Journal of Money, Credit \& Banking (Ohio State University Press) 38, 357-374.

Huyghebaert, Nancy, and Mathieu Luypaert, 2009, Value creation in mergers and acquisitions: A study of european transactions during the fifth wave, .

Ince, Ozgur S., and R. B. Porter, 2004, Individual Equity Return Data from Thomson Datastream: Handle with Care! SSRN eLibrary .

Jain, Prem C., 1985, The Effect of Voluntary Sell-Off Announcements on Shareholder Wealth, Journal of Finance 40, 209-224.

Jegadeesh, Narasimhan, and Sheridan Titman, 1993, Returns to Buying Winners and Selling Losers: Implications for Stock Market Efficiency, The Journal of Finance 48, pp. 65-91.

Jensen, Michael C., 1986, Agency Costs of Free Cash Flow, Corporate Finance, and Takeovers, The American Economic Review 76, pp. 323-329.

Kaplan, Steven N., and Luigi Zingales, 1997, Do Investment-Cash Flow Sensitivities Provide Useful Measures of Financing Constraints? Quarterly Journal of Economics 112, 169-215.

---. 2000, Investment-Cash Flow Sensitivities are Not Valid Measures of Financing Constraints, Quarterly Journal of Economics 115, 707-712.

Keen, Michael, 2002, The German Tax Reform of 2000, International Tax and Public Finance 9, 603-621.

Kengelbach, Jens, and Alexander Roos, 2006, Entflechtung der Deutschland AG - Empirische Untersuchung der Reduktion von Kapital- und Personalverflechtungen zwischen deutschen börsennotierten Gesellschaften, M\&A Review 1, 12-21.

Klein, April, 1986, The Timing and Substance of Divestiture Announcements: Individual, Simultaneous and Cumulative Effects, Journal of Finance 41, 685-696.

Lang, Larry H. P., René M. Stulz, and Ralph A. Walkling, 1991, A test of the free cash flow hypothesis: The case of bidder returns, Journal of Financial Economics 29, 315-335.

Lang, Larry, Annette Poulsen, and René Stulz, 1995, Asset sales, firm performance, and the agency costs of managerial discretion, Journal of Financial Economics 37, 3-37. 
Masulis, Ronald W., Cong Wang, and Fei Xie, 2007, Corporate Governance and Acquirer Returns, The Journal of Finance 62, 1851-1889.

Modigliani, Franco, and Merton H. Miller, 1958, The Cost of Capital, Corporation Finance and the Theory of Investment, The American Economic Review 48, pp. 261-297.

Moeller, Sara B., Frederik P. Schlingemann, and Rene M. Stulz, 2005, Wealth Destruction on a Massive Scale? A Study of Acquiring-Firm Returns in the Recent Merger Wave, The Journal of Finance 60, 757-782.

Moyen, Nathalie, 2004, Investment-Cash Flow Sensitivities: Constrained versus Unconstrained Firms, The Journal of Finance 59, 2061-2092.

Myers, Stewart C., and Nicholas S. Majluf, 1984, Corporate financing and investment decisions when firms have information that investors do not have, Journal of Financial Economics 13, 187-221.

Opler, Tim, Lee Pinkowitz, René Stulz, and Rohan Williamson, 1999, The determinants and implications of corporate cash holdings, Journal of Financial Economics 52, 3-46.

Pauly, Christoph, and Ulrich Schäfer, 2002, Jäger des verlorenen Schatzes, Spiegel (09.09.2002) http://www.spiegel.de/spiegel/print/d-24793156.html .

Pinkowitz, Lee F., Rene M. Stulz, and Rohan G. Williamson, 2006, Does the Contribution of Corporate Cash Holdings and Dividends to Firm Value Depend on Governance? A Crosscountry Analysis, The Journal of Finance 61, 2725-2751.

Puhani, Patrick A., 2012, The treatment effect, the cross difference, and the interaction term in nonlinear “difference-in-differences” models, Economics Letters 115, 85-87.

Rauh, Joshua D., 2006, Investment and Financing Constraints: Evidence from the Funding of Corporate Pension Plans, The Journal of Finance 61, pp. 33-71.

Sautner, Zacharias, and Belen Villalonga, 2010, Corporate Governance and Internal Capital Markets, SSRN eLibrary .

Stein, Jeremy C., 2003, Chapter 2 Agency, information and corporate investment, in Anonymous Handbook of the Economics of Finance (Elsevier).

von Beschwitz, Bastian, and Daniel Foos, 2014, Banks' equity stakes and Lending: Evidence from a Tax Reform, Working Paper.

Weber, Anke, 2009, An empirical analysis of the 2000 corporate tax reform in Germany: Effects on ownership and control in listed companies, International Review of Law and Economics 29, 57-66.

Whited, Toni M., 1992, Debt, Liquidity Constraints, and Corporate Investment: Evidence from Panel Data, The Journal of Finance 47, pp. 1425-1460.

Williamson, Oliver E., 1964, The Economics of Discretionary Behavior: Managerial Objectives in a Theory of the Firm, Englewood Cliffs, N.J.: Prentice-Hall . 


\section{Figure 1: Event Study: Announcement of the Tax Reform}

In Panel A displays mean returns of companies with and without equity stakes around the announcement of the tax reform on $23^{\text {rd }}$ December 1999. Panel B displays the difference in daily mean returns between companies with large equity stakes and companies without equity stakes. A Company is defined as having large equity stakes if its equity stakes have an aggregate value of at least 1 percent of its market capitalization. Panel C splits the returns for companies with large equity stakes into financial and non-financial companies. For Panel C, ***, **, * indicate significance at the $1 \%, 5 \%$ and $10 \%$ level, based on a time series comparison from July 1999 to June 2000. An equity stake is defined as holding $20 \%$ or less of another company's equity, which is either held directly or through a chain of subsidiaries at the $75 \%$ threshold.

\section{Panel A: Stock Returns around the Announcement of the Tax Reform}

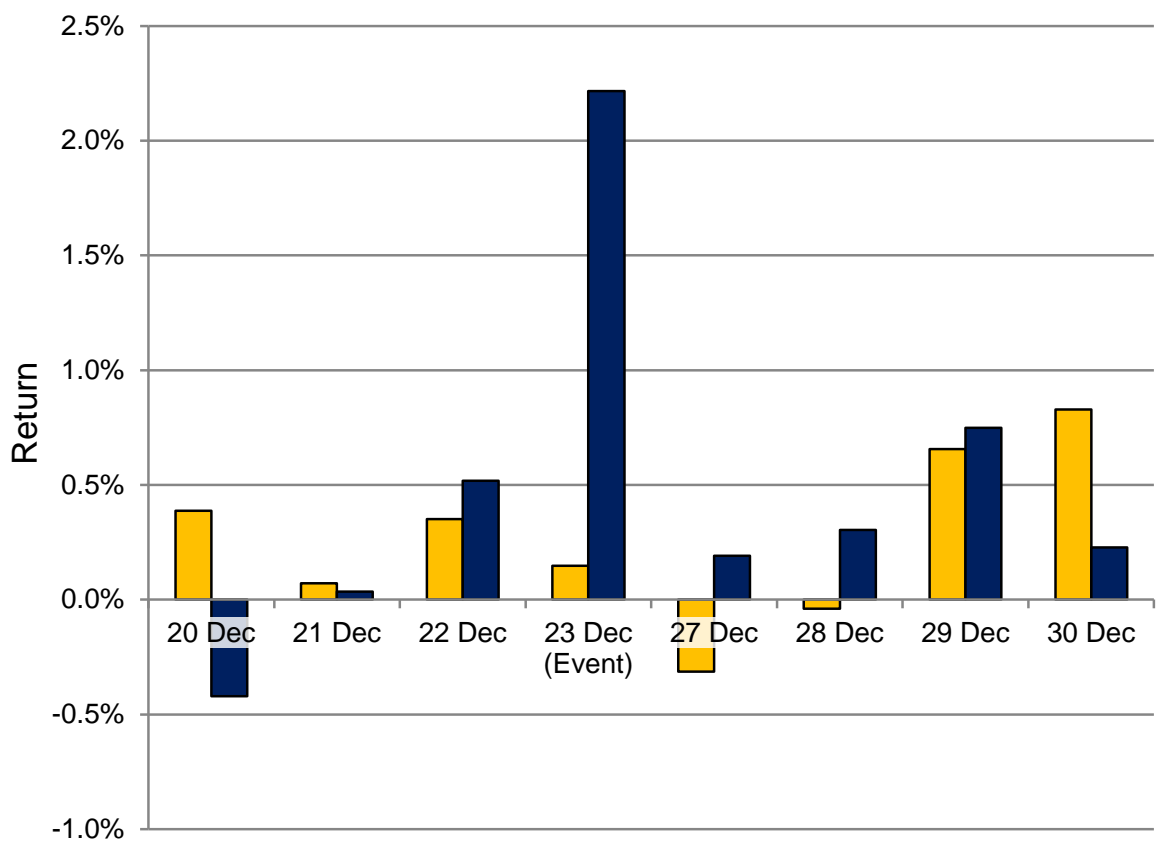

Panel B: Return difference with large equity stakes and without equity stakes

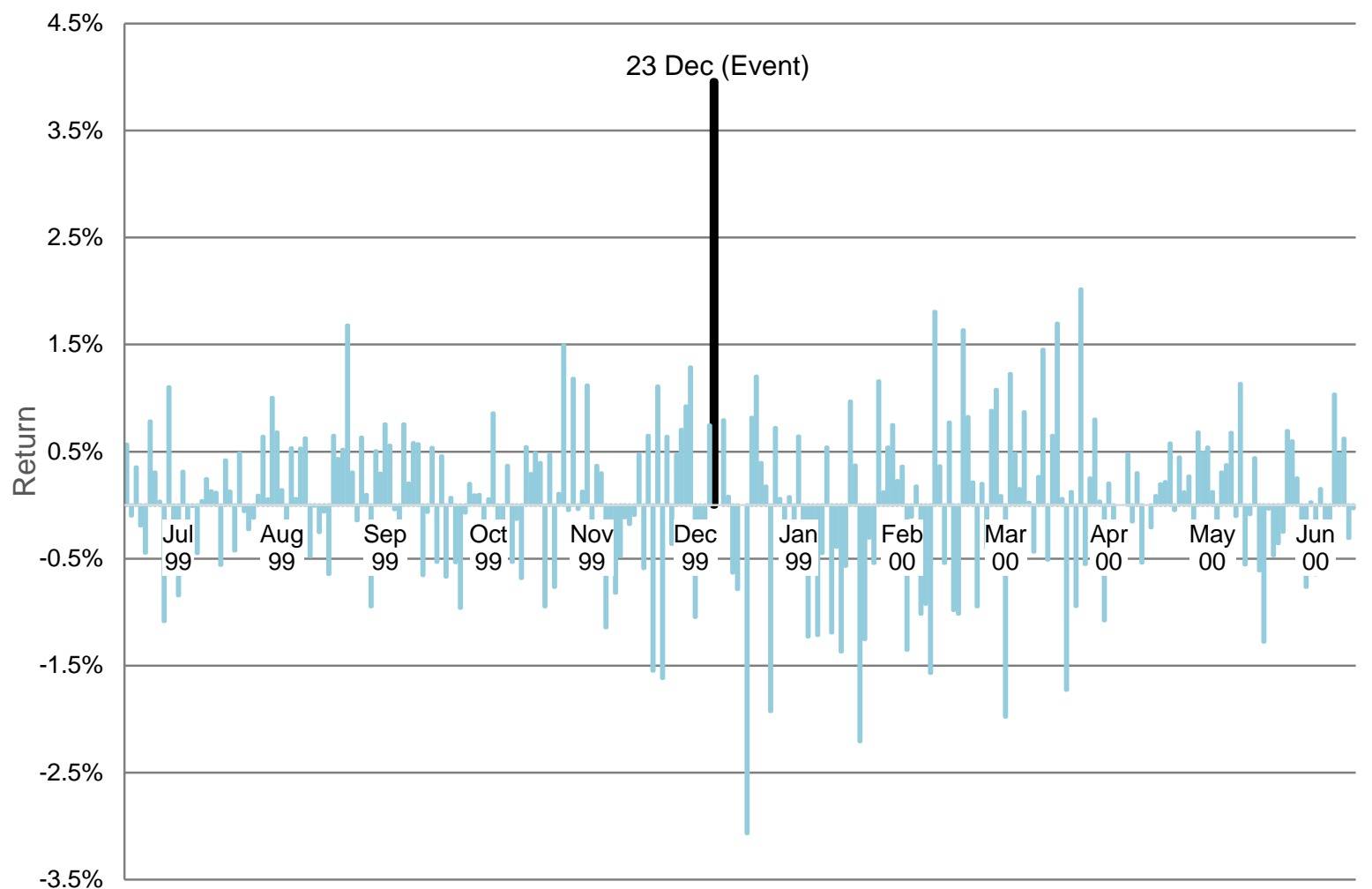




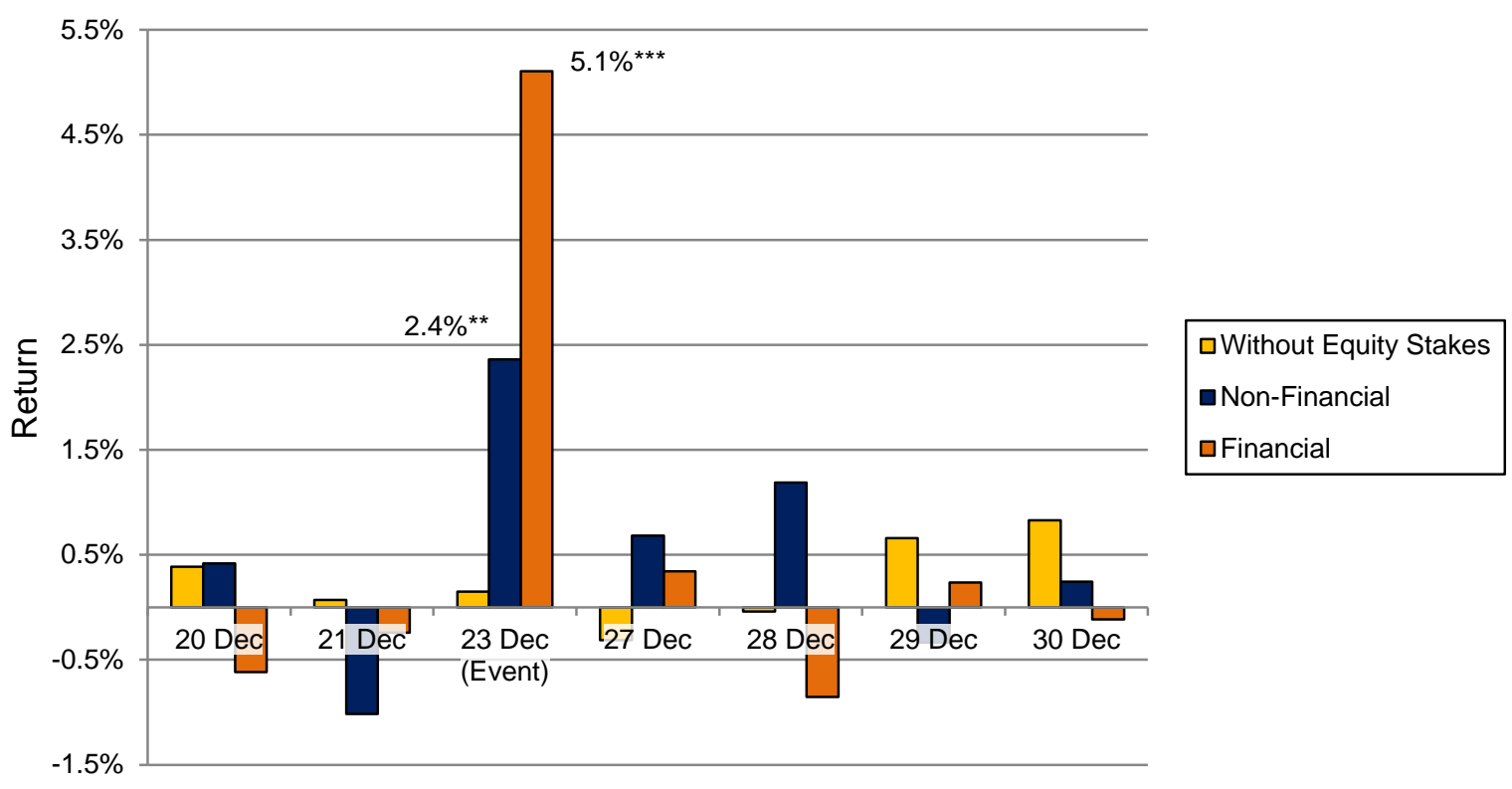

\section{Figure 2: Companies by Industry}

This figure displays the companies with equity stakes in 1999 and the companies without equity stakes in 1999 according to the 10 Fama French industry groups. An equity stake is defined as holding $20 \%$ or less of another company's equity, which is either held directly or through a chain of subsidiaries at the $75 \%$ threshold.

\section{Companies by 10 Fama French Industries}

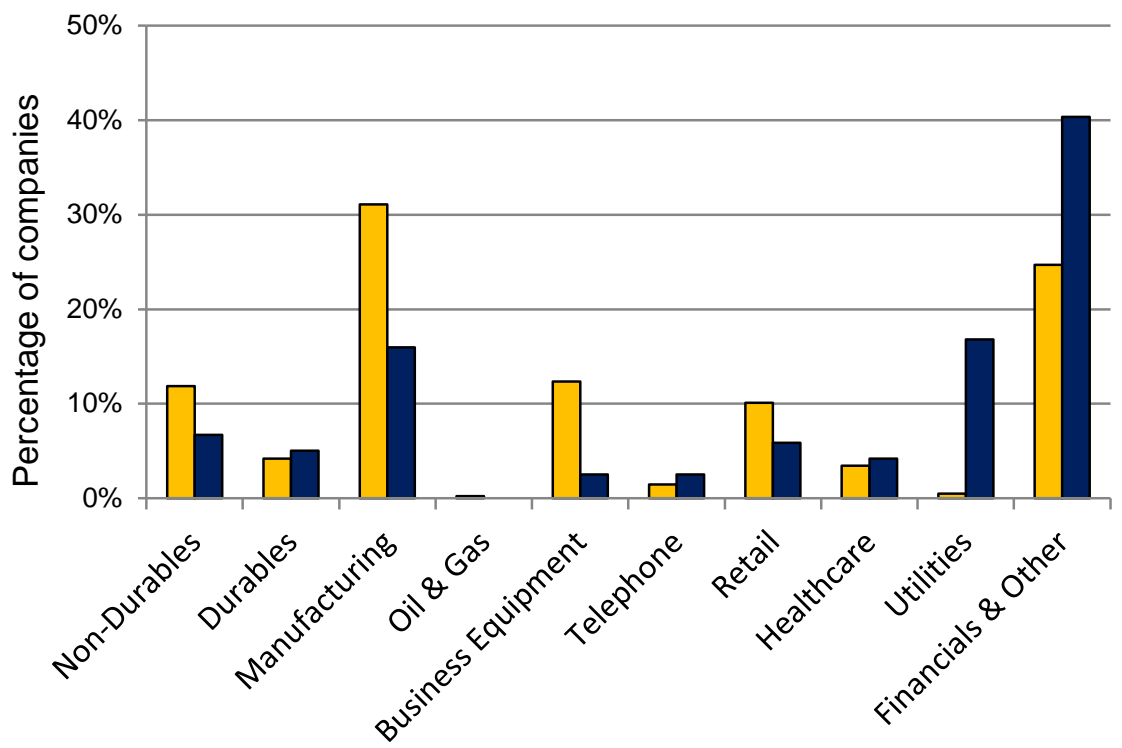




\section{Figure 3: Change in Acquisition Probability}

This figure displays the average percentage of companies in a certain year that undertook an acquisition. In the first graph, I display this average for companies with equity stakes in 1999 and in the second graph for companies without equity stakes in 1999. The "before tax reform" period is 1992 to 1999; the "after tax reform" period is 2000 to 2007.

\section{Changes in Acquisition Probability Following the Tax Reform}

With Equity Stakes

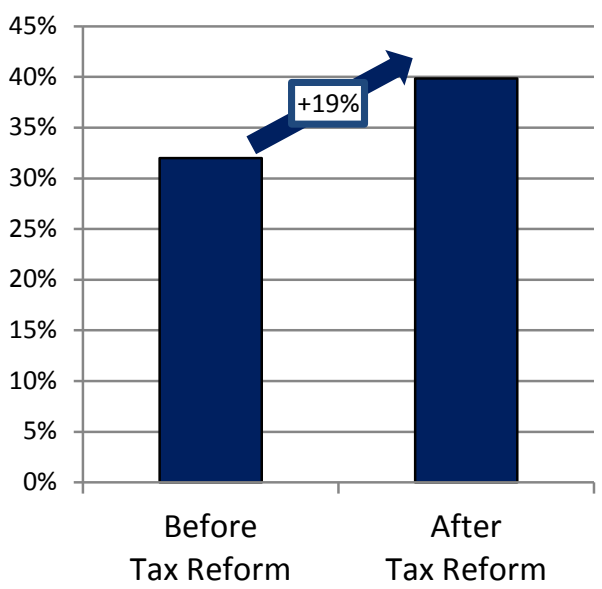

Without Equity Stakes

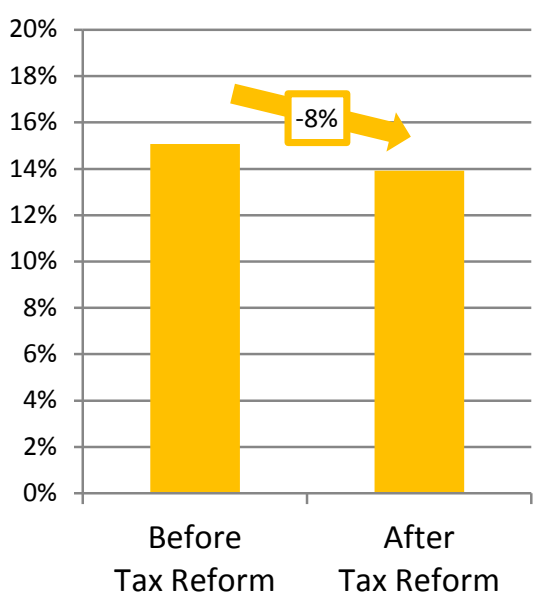

\section{Figure 4: Effect of Cash Windfall on Acquisition Probability by Year}

This figure reports the point estimates from a logit regression conditional on firms of Acquisition Dummy on the interaction between Equity Stake 1999 and yearly dummies from 1994 to 2007. Additional controls in the regression include year fixed effects as well as Size, Leverage and Tobin's Q in 1999 interacted with Post Reform. The specification is the same as that reported in Table 4 Regressions 1, except that Equity Stake 1999 is interacted with yearly dummies from 1994 to 2007 instead of Post Reform. The two vertical lines indicate the announcement of the tax reform in December 1999 and the tax reform coming into effect in January 2002.

\section{Acquisition Probability (Log Odds Ratio)}

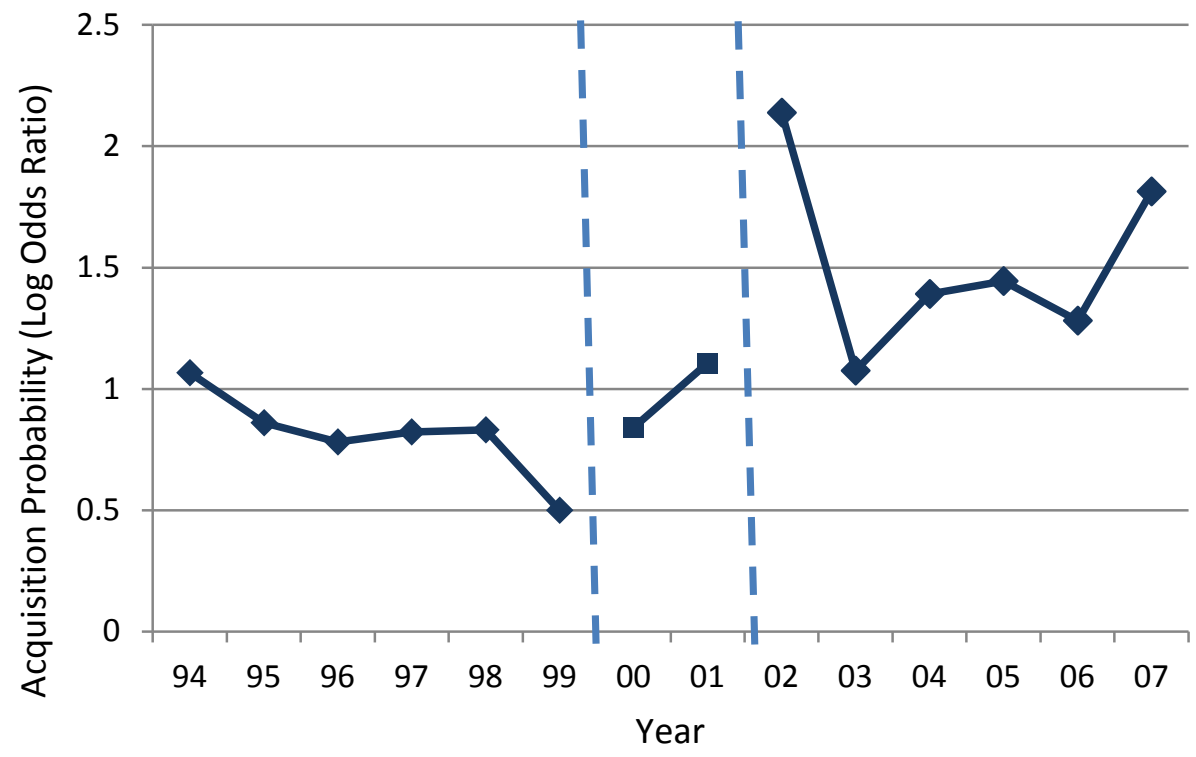




\section{Figure 5: Change in Average Announcement return}

This figure displays the average acquirer announcement return from $t-1$ to $t+1$ trading days around the acquisition. In the first graph, I display this average for companies with equity stakes in 1999 and in the second graph for companies without equity stakes in 1999. The "before tax reform” period goes from 1992 to 1999; the “after tax reform” period goes from 2000 to 2007. In the Panel A, I display cumulative raw returns. In Panel B, I display cumulative one-factor alphas. In Panel C, I display cumulative four-factor alphas.

Panel A: Raw Return $t-1$ to $t+1$

With Equity Stake

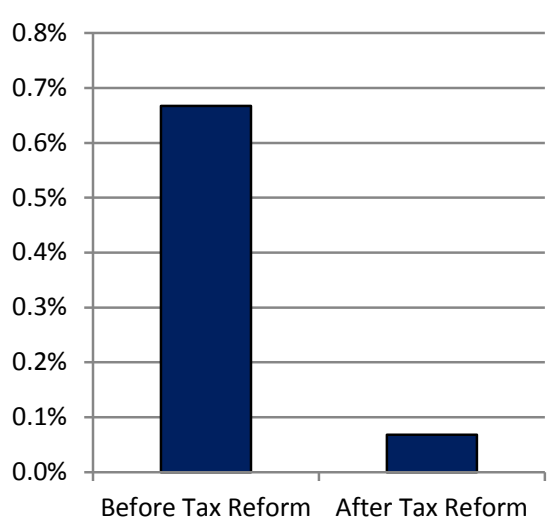

Without Equity Stake

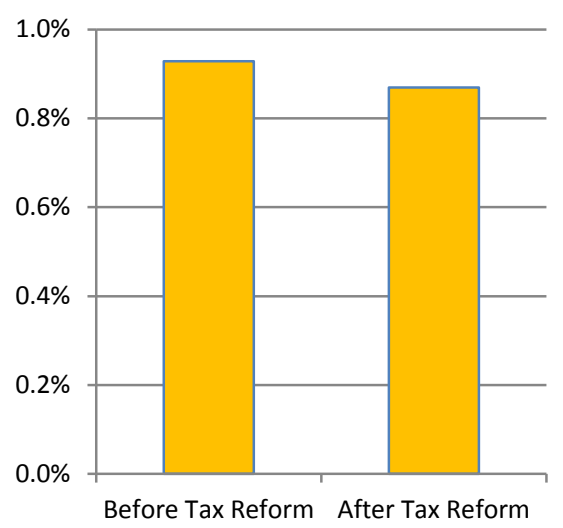

Panel B: One-Factor Alpha $t-1$ to $t+1$

With Equity Stake

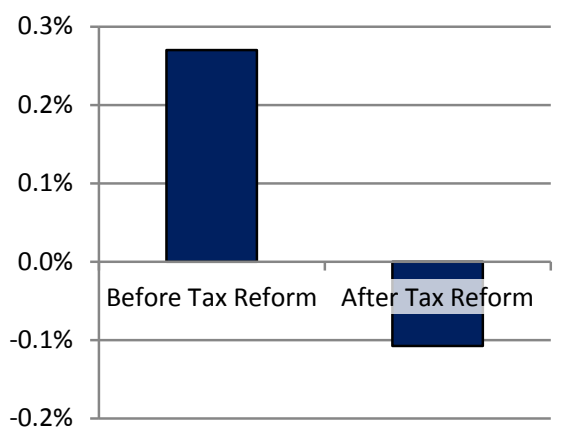

Without Equity Stake

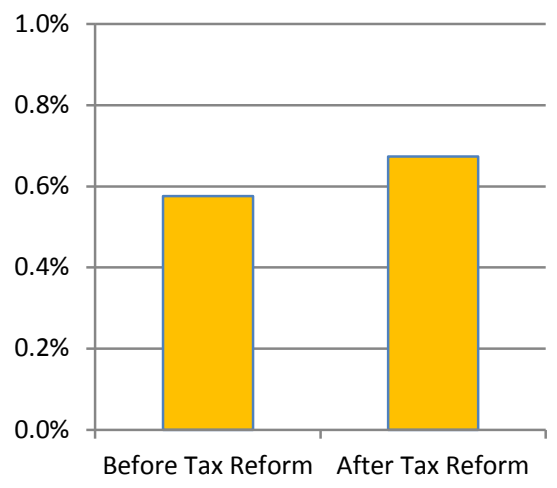

Panel C: Four-Factor Alpha $t-1$ to $t+1$

With Equity Stake

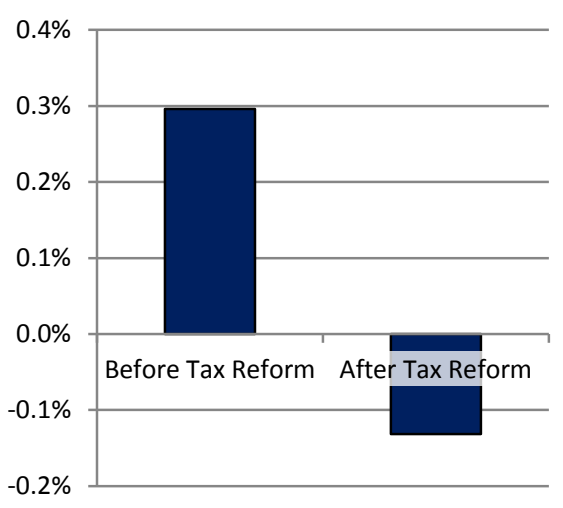

Without Equity Stake

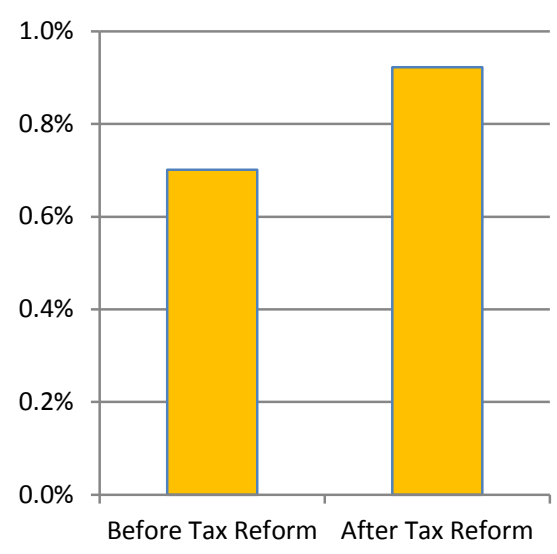




\section{Figure 6: Effect of Cash Windfall on Announcement Return by Year}

This figure reports the point estimates from an acquisition-level panel regression of Announcement Returns on the interaction between Equity Stake 1999 and yearly dummies from 1994 to 2007. The dependent variable is the cumulative return from t-1 to t+1 around the acquisition announcement date. Additional controls in the regression include firm and year fixed effects as well as Size, Leverage and Tobin's Q in 1999 interacted with Post Reform and industry fixed effects interacted with yearly dummies. The specification is the same as that reported in Table 5 Regressions 1, except that Equity Stake 1999 is interacted with year dummies from 1994 to 2007 instead of Post Reform. The two vertical lines indicate the announcement of the tax reform in December 1999 and the tax reform coming into effect in January 2002.

\section{Announcement Return}

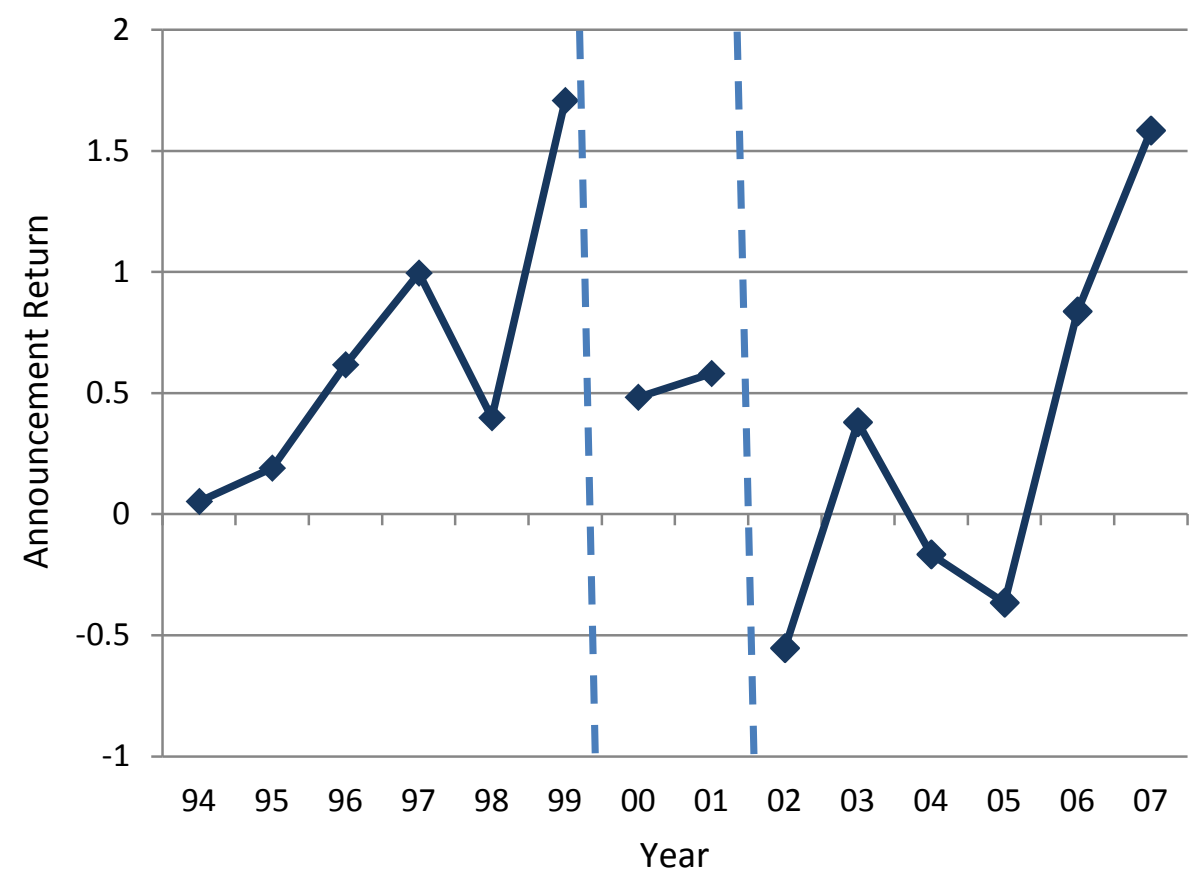




\section{Table 1: Hypotheses and Results}

This table displays the different hypotheses of how a positive cash shock should influence certain variables and compares it to our results.

\begin{tabular}{|c|c|c|c|c|}
\hline Variables & $\begin{array}{l}\text { Modigliani } \\
\text { Miller }\end{array}$ & $\begin{array}{l}\text { Non-agency } \\
\text { financial } \\
\text { constraints } \\
\text { theory }\end{array}$ & $\begin{array}{c}\text { Free cash flow } \\
\text { theory }\end{array}$ & Result \\
\hline Number of Acquisitions & no effect & increase & increase & increase \\
\hline Capital Expenditures & no effect & increase & increase & (increase) \\
\hline Average Announcement Returns & no effect & small decrease & large decrease & large decrease \\
\hline Sum of Announcement Returns & no effect & increase & decrease & decrease \\
\hline
\end{tabular}

\section{Table 2: Summary Statistics}

Panel A displays summary statistics of the sample, split by whether a company holds an equity stake in another company in 1999. Variables are taken as of the last fiscal year ending before 31st December 1999. The test for the difference in median is the Wilcoxon rank-sum test. The test for the difference in mean is the Student t-test. Tobin's $Q$ is defined as market capitalization divided by book value of equity. Leverage is defined as book value of debt divided by book value of assets. Dividends Ratio is defined as total dividends over total assets. Return on Assets is defined as EBIT over total assets. Panel B displays summary statistics on equity stakes for those firms that held at least one equity stake. Number of Equity Stakes gives the number of equity stakes a firm owns. Value of Equity Stakes (million EUR) is my estimate of the sum of their value. Value of Equity Stakes (in \% of market cap) is this sum divided by the firm's own market value in percentage points. Panel C displays summary statistics on the acquisition level. Acquirer Announcement Return is the stock return of the acquirer from one day before to three days after the acquisition. Diversifying Acquisition is a dummy equal to one if the target operates in another industry (10 Fama French). Cross-Border Deal is a dummy equal to one if the target is not located in Germany. Cash Acquisition is a dummy variable equal to one if the acquisition was paid exclusively in cash (and missing if SDC Platinum does not provide payment information). No Payment Information is a dummy equal to one if the information of the payment method is not available in SDC Platinum. ***, **, * indicate significance at the $1 \%, 5 \%$ and $10 \%$ level.

Panel A: Firms

\begin{tabular}{|c|c|c|c|c|c|c|}
\hline \multirow[b]{2}{*}{ Variable } & \multicolumn{2}{|c|}{ Without Equity Stakes } & \multicolumn{2}{|c|}{ With Equity Stakes } & \multirow{2}{*}{$\begin{array}{l}\mathrm{Z} \text { test for } \\
\text { Difference } \\
\text { in Median }\end{array}$} & \multirow{2}{*}{$\begin{array}{c}\mathrm{T} \text { test for } \\
\text { Difference in } \\
\text { Mean }\end{array}$} \\
\hline & Median & Mean & Median & Mean & & \\
\hline Tobin’s Q & 1.87 & 2.32 & 2.01 & 2.32 & -0.973 & -0.057 \\
\hline Market capitalization (log) & 18.4 & 18.5 & 21.1 & 20.9 & $-9.89 * * *$ & $-12.6 * * *$ \\
\hline Leverage & 0.15 & 0.20 & 0.17 & 0.23 & -0.762 & -1.50 \\
\hline Dividends Ratio & 0.0072 & 0.015 & 0.0086 & 0.015 & $-1.87^{*}$ & -0.092 \\
\hline Return on Assets & 0.063 & 0.055 & 0.054 & 0.065 & 0.596 & -0.78 \\
\hline Number of Firms & \multicolumn{2}{|c|}{381} & \multicolumn{2}{|c|}{115} & & \\
\hline
\end{tabular}

Panel B: Firms with Equity Stakes

\begin{tabular}{|c|c|c|c|c|c|}
\hline Variable & Mean & $\begin{array}{c}10^{\text {th }} \\
\text { Percentile }\end{array}$ & Median & $\begin{array}{c}90^{\text {th }} \\
\text { Percentile }\end{array}$ & $\begin{array}{c}\text { Standard } \\
\text { Deviation }\end{array}$ \\
\hline Number of Equity Stakes & 4.91 & 1 & 2 & 14 & 7.96 \\
\hline Value of Equity Stakes (million EUR) & 646.2 & 0.20 & 7.38 & 498.9 & 2719.8 \\
\hline Value of Equity Stakes (in \% of market cap) & 24.2 & 0.020 & 0.73 & 24.6 & 122.7 \\
\hline Observations & 115 & & & & \\
\hline
\end{tabular}

Panel C: Acquisitions

\begin{tabular}{|c|c|c|c|c|c|}
\hline Variable & Mean & $\begin{array}{c}10^{\text {th }} \\
\text { Percentile }\end{array}$ & Median & $\begin{array}{c}90^{\text {th }} \\
\text { Percentile }\end{array}$ & $\begin{array}{l}\text { Standard } \\
\text { Deviation }\end{array}$ \\
\hline Acquirer Announcement Return t-1,t+1 (\%) & 0.59 & -3.67 & 0.24 & 5.25 & 3.93 \\
\hline Diversifying Acquisition & 0.35 & 0 & 0 & 1 & 0.48 \\
\hline Cross-Border Deal & 0.59 & 0 & 1 & 1 & 0.49 \\
\hline Public Target & 0.55 & 0 & 1 & 1 & 0.50 \\
\hline Independent Target & 0.53 & 0 & 1 & 1 & 0.50 \\
\hline Cash Acquisition & 0.86 & 0 & 1 & 1 & 0.35 \\
\hline No Payment Information & 0.74 & 0 & 1 & 1 & 0.44 \\
\hline Observations & 3378 & & & & \\
\hline
\end{tabular}




\section{Table 3: Divestitures of Equity Stakes until 2006}

Panel A displays how many of the equity stakes were divested until November 2006. An equity stake is defined as sold if it has been divested by at least $50 \%$. If the firm in which the stake is held is not covered anymore in the data, the equity stake is listed under not covered. In Panel B, I display how many companies sold at least one equity stake. Again I employ the $50 \%$ threshold. The data comes from Who owns Whom? in November 2006, but has been manually checked and adjusted accordingly.

\section{Panel A: Equity Stakes}

\begin{tabular}{lccc}
\hline Variable & Number & $\begin{array}{c}\text { Percentage } \\
\text { with data }\end{array}$ & Total Percentage \\
\hline Equity stake sold & 256 & 61.1 & 43.2 \\
Equity stake not sold & 163 & 38.9 & 27.5 \\
Not covered & 174 & - & 29.3 \\
\hline Total & 593 & 100 & \\
\hline
\end{tabular}

Panel B: Companies

\begin{tabular}{lccc}
\hline Variable & Number & $\begin{array}{c}\text { Percentage } \\
\text { with data }\end{array}$ & Total Percentage \\
\hline At least one equity stake sold & 96 & 83.2 & 65.9 \\
No equity stake sold & 6 & 16.8 & 13.3 \\
Not covered & 33 & - & 20.7 \\
\hline Total & 135 & 100 & 100 \\
\hline
\end{tabular}

\section{Table 4: Acquisition Probability}

This table displays yearly panel regressions of Acquisition Dummy on the interaction of Equity Stake 1999 and Post Reform. Acquisition Dummy equals one if a company undertakes an acquisition in a year and zero if it did not undertake an acquisition, but was covered in Worldscope or Compustat Global. The indicator variable Post Reform takes the value of one for the years 2000 to 2007 and zero for the years 1992 to 1999. Equity Stake 1999 is an indicator variable equal to one if the company owned an equity stake at the $20 \%$ threshold in 1999 . Size is the natural logarithm of market capitalization in 1999. Tobin's $Q$ is defined as market capitalization divided by total equity in 1999 . Leverage is defined as debt divided by total assets in 1999. In Regression 1, I employ logit estimation conditional on firms. In Regressions 2 and 3 , I employ OLS estimation with firm fixed effects. All standard errors are clustered at the firm level. I report t-statistics below the coefficients in parenthesis. $* * *, * *, *$ indicate significance at the $1 \%, 5 \%$ and $10 \%$ level.

\begin{tabular}{|c|c|c|c|}
\hline & \multicolumn{3}{|c|}{ Acquisition Dummy } \\
\hline & $(1)$ & $(2)$ & $(3)$ \\
\hline \multirow[t]{2}{*}{ Equity Stake $1999 *$ Post Reform } & $0.627^{* *}$ & $0.075^{* * *}$ & $0.080^{* * *}$ \\
\hline & $(2.18)$ & $(2.82)$ & $(2.74)$ \\
\hline \multirow[t]{2}{*}{ Size * Post Reform } & 0.070 & -0.003 & -0.003 \\
\hline & $(0.89)$ & $(-0.66)$ & $(-0.57)$ \\
\hline \multirow[t]{2}{*}{ Leverage * Post Reform } & $-1.192^{*}$ & $-0.119^{* *}$ & $-0.131^{* *}$ \\
\hline & $(-1.93)$ & $(-2.20)$ & $(-2.39)$ \\
\hline \multirow[t]{2}{*}{ Tobin's Q * Post Reform } & $-0.167^{*}$ & -0.006 & -0.005 \\
\hline & $(-1.76)$ & $(-0.78)$ & $(-0.69)$ \\
\hline Observations & 3325 & 6090 & 6090 \\
\hline Adjusted $R^{2}$ & & 0.42 & 0.42 \\
\hline Regression Type & Cond. Logit & OLS & OLS \\
\hline Condition on & Firm & & \\
\hline Firm Fixed Effects & No & Yes & Yes \\
\hline Year Fixed Effects & Yes & Yes & No \\
\hline Industry-Year F.E. & No & No & Yes \\
\hline
\end{tabular}




\section{Table 5: Announcement Returns}

This table displays OLS regressions of acquirer announcement returns (in percentage points) on the interaction of Equity Stake 1999 and Post Reform. The sample for this regression consists of all acquisitions from 1992 to 2007. In regressions 1 and 2, the dependent variable is the cumulative return from t-1 to t+1 around the announcement date of the acquirer. In regressions 3 to 6 , I replace returns with alphas based on a classical CAPM with only one market factor and the Carhart (1997) four-factor model. I construct the respective factors for Germany (see Appendix 2). Cash Acquisition is a dummy variable equal to one if the acquisition was paid exclusively in cash. No Payment Information is an indicator variable equal to one if the information of the payment method is not available in SDC Platinum. Diversifying Acquisition is a dummy equal to one if the target operates in another industry. Cross-Border Deal is a dummy equal to one if the target is not located in Germany. Public Target is a dummy equal to one if the target has a SEDOL. Independent Target is equal to one if there is no parent company given in SDC Platinum. All standard errors are clustered at the firm level. I report t-statistics below the coefficients in parenthesis. ***, **, * indicate significance at the $1 \%, 5 \%$ and $10 \%$ level.

\begin{tabular}{|c|c|c|c|c|c|c|}
\hline & \multicolumn{2}{|c|}{$\begin{array}{c}\text { Announcement } \\
\text { Return } \mathrm{t}-1 \text { to } \mathrm{t}+1 \\
\end{array}$} & \multicolumn{2}{|c|}{$\begin{array}{c}\text { Announcement One-Factor } \\
\text { Alpha t- } 1 \text { to } t+1\end{array}$} & \multicolumn{2}{|c|}{$\begin{array}{c}\text { Announcement Four-Factor } \\
\text { Alpha t- } 1 \text { to } t+1\end{array}$} \\
\hline & (1) & (2) & (3) & (4) & (5) & (6) \\
\hline Equity Stake 1999 * Post Reform & $\begin{array}{l}-1.18^{* *} \\
(-2.10)\end{array}$ & $\begin{array}{l}-1.24^{* *} \\
(-2.14)\end{array}$ & $\begin{array}{l}-0.97^{*} \\
(-1.94)\end{array}$ & $\begin{array}{l}-1.03^{* *} \\
(-2.01)\end{array}$ & $\begin{array}{l}-0.92^{*} \\
(-1.91)\end{array}$ & $\begin{array}{l}-0.97^{*} \\
(-1.97)\end{array}$ \\
\hline Avg. Return $(-365,-20)$ & $\begin{array}{l}1.42^{*} \\
(1.89)\end{array}$ & $\begin{array}{l}1.50^{* *} \\
(1.98)\end{array}$ & $\begin{array}{c}1.09 \\
(1.22)\end{array}$ & $\begin{array}{c}1.19 \\
(1.33)\end{array}$ & $\begin{array}{c}0.94 \\
(1.04)\end{array}$ & $\begin{array}{l}1.05 \\
(1.16)\end{array}$ \\
\hline Size * Post Reform & $\begin{array}{c}0.15 \\
(1.03)\end{array}$ & $\begin{array}{c}0.21 \\
(1.43)\end{array}$ & $\begin{array}{c}0.18 \\
(1.21)\end{array}$ & $\begin{array}{c}0.22 \\
(1.48)\end{array}$ & $\begin{array}{c}0.18 \\
(1.30)\end{array}$ & $\begin{array}{c}0.22 \\
(1.55)\end{array}$ \\
\hline Leverage * Post Reform & $\begin{array}{l}-0.01 \\
(-0.01)\end{array}$ & $\begin{array}{c}0.08 \\
(0.07)\end{array}$ & $\begin{array}{l}-0.58 \\
(-0.52)\end{array}$ & $\begin{array}{l}-0.52 \\
(-0.47)\end{array}$ & $\begin{array}{l}-0.02 \\
(-0.02)\end{array}$ & $\begin{array}{c}0.00 \\
(0.00)\end{array}$ \\
\hline Tobin's Q * Post Reform & $\begin{array}{l}-0.54^{* *} \\
(-2.48)\end{array}$ & $\begin{array}{l}-0.57^{* * *} \\
(-2.62)\end{array}$ & $\begin{array}{l}-0.42^{*} \\
(-1.81)\end{array}$ & $\begin{array}{l}-0.44^{*} \\
(-1.87)\end{array}$ & $\begin{array}{l}-0.34 \\
(-1.49)\end{array}$ & $\begin{array}{l}-0.35 \\
(-1.54)\end{array}$ \\
\hline Cash Acquisition & & $\begin{array}{l}-0.27 \\
(-0.56)\end{array}$ & & $\begin{array}{l}-0.29 \\
(-0.64)\end{array}$ & & $\begin{array}{l}-0.27 \\
(-0.61)\end{array}$ \\
\hline No Payment Information & & $\begin{array}{l}-0.53 \\
(-1.02)\end{array}$ & & $\begin{array}{l}-0.55 \\
(-1.19)\end{array}$ & & $\begin{array}{l}-0.57 \\
(-1.28)\end{array}$ \\
\hline Diversifying Acquisition & & $\begin{array}{l}0.01 \\
(0.04)\end{array}$ & & $\begin{array}{l}0.06 \\
(0.38)\end{array}$ & & $\begin{array}{c}0.05 \\
(0.35)\end{array}$ \\
\hline Cross-Border Deal & & $\begin{array}{l}-0.18 \\
(-0.79)\end{array}$ & & $\begin{array}{l}-0.32^{* *} \\
(-1.97)\end{array}$ & & $\begin{array}{l}-0.35^{* *} \\
(-2.16)\end{array}$ \\
\hline Public Target & & $\begin{array}{l}-0.48^{* *} \\
(-2.26)\end{array}$ & & $\begin{array}{l}-0.10 \\
(-0.62)\end{array}$ & & $\begin{array}{l}-0.04 \\
(-0.21)\end{array}$ \\
\hline Independent Target & & $\begin{array}{l}-0.50^{* * * *} \\
(-3.23)\end{array}$ & & $\begin{array}{l}-0.49^{* * *} \\
(-3.48)\end{array}$ & & $\begin{array}{l}-0.46^{* * *} \\
(-3.19)\end{array}$ \\
\hline Observations & 2885 & 2862 & 2852 & 2829 & 2852 & 2829 \\
\hline Adjusted $R^{2}$ & 0.10 & 0.11 & 0.12 & 0.13 & 0.12 & 0.13 \\
\hline Firm Fixed Effects & $\begin{array}{l}\text { Yes } \\
\text { Yes }\end{array}$ & $\begin{array}{l}\text { Yes } \\
\text { Yes }\end{array}$ & $\begin{array}{l}\text { Yes } \\
\text { Yes }\end{array}$ & $\begin{array}{l}\text { Yes } \\
\text { Yes }\end{array}$ & $\begin{array}{l}\text { Yes } \\
\text { Yes }\end{array}$ & $\begin{array}{l}\text { Yes } \\
\text { Yes }\end{array}$ \\
\hline
\end{tabular}




\section{Table 6: Yearly Sum of Announcement Returns}

This table displays yearly panel regressions of the Sum of Announcement Returns (in percentage points) on the interaction of Equity Stake 1999 and Post Reform. The dependent variables are the yearly sum of all announcement returns (or alphas). All standard errors are clustered at the firm level. I report t-statistics below the coefficients in parenthesis. ${ }^{* * *}, * *, *$ indicate significance at the $1 \%, 5 \%$ and $10 \%$ level.

\begin{tabular}{lccc}
\hline & \multicolumn{2}{c}{ Yearly Sum of Announcement Returns } \\
\cline { 2 - 4 } & Raw Returns & One-Factor Alpha & Four-Factor Alpha \\
\cline { 2 - 4 } & $(1)$ & $(2)$ & $(3)$ \\
\hline Equity Stake 1999 * Post Reform & $-0.584^{*}$ & $-0.599^{* *}$ & $-0.622^{* *}$ \\
& $(-1.89)$ & $(-2.31)$ & $(-2.39)$ \\
\hline Observations & 6365 & 6365 & 6365 \\
Adjusted $R^{2}$ & 0.08 & 0.04 & 0.04 \\
\hline Firm Fixed Effects & Yes & Yes & Yes \\
Industry-Year F.E. & Yes & Yes & Yes \\
\hline
\end{tabular}

\section{Table 7: Differential Effect by the Size of the Equity Stakes}

This table displays the main tests splitting the treated group by the aggregate size of their equity stakes. Large Equity Stake 1999 is a dummy variable equal to one if the company ranks above the median by value of its equity stakes (as a share of its market capitalization) in 1999, while Small Equity Stake 1999 is a dummy variable equal to one if it ranks below the median. If a company does not own minority equity stakes, these two variables are set equal to zero. Panel A displays regressions for the acquisition probability and is thus the counterpart to Table 4. In regressions 1, I run a logit regression conditional on firm. In regression 2 and 3, I run OLS regressions. Panel B displays regressions for announcement returns (in percentage points) and is thus the counterpart to Table 5. Panel C displays regressions for the yearly sum of announcement returns (in percentage points) and is thus the counterpart to Table 6. All variables are defined as above. All standard errors are clustered at the firm level. I report t-statistics below the coefficients in parenthesis. ***, **, * indicate significance at the $1 \%$, $5 \%$ and $10 \%$ level.

Panel A: Acquisition Probability

Acquisition Dummy

\begin{tabular}{|c|c|c|c|}
\hline & \\
\hline & $(1)$ & $(2)$ & (3) \\
\hline \multirow[t]{2}{*}{ Large Equity Stake $1999 *$ Post Reform } & $0.975^{* * *}$ & $0.102^{* * *}$ & $0.113^{* * *}$ \\
\hline & $(2.88)$ & (3.64) & $(3.74)$ \\
\hline \multirow[t]{2}{*}{ Small Equity Stake 1999 * Post Reform } & 0.397 & 0.045 & 0.050 \\
\hline & $(1.16)$ & $(1.08)$ & $(1.16)$ \\
\hline \multirow[t]{2}{*}{ Size * Post Reform } & 0.070 & -0.003 & -0.002 \\
\hline & $(0.91)$ & $(-0.54)$ & $(-0.47)$ \\
\hline \multirow[t]{2}{*}{ Leverage * Post Reform } & $-1.264^{* *}$ & $-0.121^{* *}$ & $-0.135^{* *}$ \\
\hline & $(-2.10)$ & $(-2.27)$ & $(-2.48)$ \\
\hline \multirow[t]{2}{*}{ Tobin's Q * Post Reform } & -0.144 & -0.005 & -0.004 \\
\hline & $(-1.52)$ & $(-0.68)$ & $(-0.56)$ \\
\hline Observations & 3325 & 6090 & 6090 \\
\hline Adjusted $R^{2}$ & & 0.42 & 0.42 \\
\hline Regression Type & Cond. Logit & OLS & OLS \\
\hline Condition on & Firm & & \\
\hline Firm Fixed Effects & No & Yes & Yes \\
\hline Year Fixed Effects & Yes & Yes & No \\
\hline Industry-Year F.E. & No & No & Yes \\
\hline
\end{tabular}


Panel B: Announcement Returns

\begin{tabular}{|c|c|c|c|c|c|c|}
\hline & \multicolumn{2}{|c|}{$\begin{array}{c}\text { Announcement Return } \\
\text { t- } 1 \text { to } t+1\end{array}$} & \multicolumn{2}{|c|}{$\begin{array}{l}\text { Announcement One-Factor } \\
\text { Alpha } t-1 \text { to } t+1\end{array}$} & \multicolumn{2}{|c|}{$\begin{array}{c}\text { Announcement Four-Factor } \\
\text { Alpha t- } 1 \text { to } t+1\end{array}$} \\
\hline & (1) & (2) & $(3)$ & (4) & $(5)$ & $(6)$ \\
\hline Large Equity Stake $1999 *$ Post Reform & $\begin{array}{l}-1.94^{* * *} \\
(-2.65)\end{array}$ & $\begin{array}{l}-1.99^{* * *} \\
(-2.62)\end{array}$ & $\begin{array}{l}-1.71^{* *} \\
(-2.57)\end{array}$ & $\begin{array}{l}-1.75^{* *} \\
(-2.53)\end{array}$ & $\begin{array}{l}-1.53^{* *} \\
(-2.32)\end{array}$ & $\begin{array}{l}-1.57^{* *} \\
(-2.30)\end{array}$ \\
\hline Small Equity Stake $1999 *$ Post Reform & $\begin{array}{l}-0.89 \\
(-1.44)\end{array}$ & $\begin{array}{l}-0.95 \\
(-1.50)\end{array}$ & $\begin{array}{l}-0.68 \\
(-1.22)\end{array}$ & $\begin{array}{l}-0.74 \\
(-1.32)\end{array}$ & $\begin{array}{l}-0.68 \\
(-1.26)\end{array}$ & $\begin{array}{l}-0.73 \\
(-1.35)\end{array}$ \\
\hline Avg. Return $(-365,-20)$ & $\begin{array}{l}1.35^{*} \\
(1.83)\end{array}$ & $\begin{array}{c}1.44^{*} \\
(1.93)\end{array}$ & $\begin{array}{l}1.03 \\
(1.19)\end{array}$ & $\begin{array}{c}1.14 \\
(1.31)\end{array}$ & $\begin{array}{c}0.90 \\
(1.01)\end{array}$ & $\begin{array}{c}1.01 \\
(1.13)\end{array}$ \\
\hline Size * Post Reform & $\begin{array}{c}0.21 \\
(1.44)\end{array}$ & $\begin{array}{l}0.27^{*} \\
(1.81)\end{array}$ & $\begin{array}{c}0.24 \\
(1.59)\end{array}$ & $\begin{array}{l}0.28^{*} \\
(1.84)\end{array}$ & $\begin{array}{c}0.23 \\
(1.59)\end{array}$ & $\begin{array}{c}0.27^{*} \\
(1.82)\end{array}$ \\
\hline Leverage * Post Reform & $\begin{array}{l}-0.06 \\
(-0.06)\end{array}$ & $\begin{array}{c}0.01 \\
(0.01)\end{array}$ & $\begin{array}{l}-0.64 \\
(-0.57)\end{array}$ & $\begin{array}{l}-0.59 \\
(-0.52)\end{array}$ & $\begin{array}{l}-0.07 \\
(-0.07)\end{array}$ & $\begin{array}{l}-0.05 \\
(-0.05)\end{array}$ \\
\hline Tobin's Q * Post Reform & $\begin{array}{l}-0.61^{* * *} \\
(-2.68)\end{array}$ & $\begin{array}{l}-0.64^{* * *} \\
(-2.80)\end{array}$ & $\begin{array}{l}-0.49^{* *} \\
(-2.00)\end{array}$ & $\begin{array}{l}-0.51^{* *} \\
(-2.05)\end{array}$ & $\begin{array}{l}-0.40 \\
(-1.65)\end{array}$ & $\begin{array}{l}-0.41^{*} \\
(-1.69)\end{array}$ \\
\hline Cash Acquisition & & $\begin{array}{l}-0.28 \\
(-0.58)\end{array}$ & & $\begin{array}{l}-0.30 \\
(-0.66)\end{array}$ & & $\begin{array}{l}-0.28 \\
(-0.63)\end{array}$ \\
\hline No Payment Information & & $\begin{array}{l}-0.53 \\
(-1.03)\end{array}$ & & $\begin{array}{l}-0.55 \\
(-1.20)\end{array}$ & & $\begin{array}{l}-0.57 \\
(-1.28)\end{array}$ \\
\hline Diversifying Acquisition & & $\begin{array}{l}0.00 \\
(0.01)\end{array}$ & & $\begin{array}{l}0.05 \\
(0.34)\end{array}$ & & $\begin{array}{l}0.05 \\
(0.31)\end{array}$ \\
\hline Cross-Border Deal & & $\begin{array}{l}-0.19 \\
(-0.81)\end{array}$ & & $\begin{array}{l}-0.32^{* *} \\
(-2.01)\end{array}$ & & $\begin{array}{l}-0.35^{* *} \\
(-2.18)\end{array}$ \\
\hline Public Target & & $\begin{array}{l}-0.48^{* *} \\
(-2.27)\end{array}$ & & $\begin{array}{l}-0.10 \\
(-0.62)\end{array}$ & & $\begin{array}{l}-0.03 \\
(-0.20)\end{array}$ \\
\hline Independent Target & & $\begin{array}{l}-0.49^{* * *} \\
(-3.16)\end{array}$ & & $\begin{array}{l}-0.48^{* * *} \\
(-3.40)\end{array}$ & & $\begin{array}{l}-0.45^{* * *} \\
(-3.14)\end{array}$ \\
\hline Observations & 2885 & 2862 & 2852 & 2829 & 2852 & 2829 \\
\hline Adjusted $R^{2}$ & 0.10 & 0.11 & 0.12 & 0.13 & 0.12 & 0.13 \\
\hline $\begin{array}{l}\text { Firm Fixed Effects } \\
\text { Industry-Year F.E. }\end{array}$ & $\begin{array}{l}\text { Yes } \\
\text { Yes }\end{array}$ & $\begin{array}{l}\text { Yes } \\
\text { Yes }\end{array}$ & $\begin{array}{l}\text { Yes } \\
\text { Yes }\end{array}$ & $\begin{array}{l}\text { Yes } \\
\text { Yes }\end{array}$ & $\begin{array}{l}\text { Yes } \\
\text { Yes }\end{array}$ & $\begin{array}{l}\text { Yes } \\
\text { Yes }\end{array}$ \\
\hline
\end{tabular}

Panel C: Yearly Sum of Announcement Returns

\begin{tabular}{|c|c|c|c|}
\hline & $\begin{array}{c}\text { Yearly Sum of } \\
\text { Announcement } \\
\text { Returns }\end{array}$ & $\begin{array}{c}\text { Yearly Sum of } \\
\text { Announcement } \\
\text { One-Factor Alphas }\end{array}$ & $\begin{array}{c}\text { Yearly Sum of } \\
\text { Announcement } \\
\text { Four-Factor Alphas }\end{array}$ \\
\hline & $(1)$ & $(2)$ & (3) \\
\hline Large Equity Stake 1999 * Post Reform & $\begin{array}{l}-0.770^{*} \\
(-1.95)\end{array}$ & $\begin{array}{l}-0.799^{* *} \\
(-2.36)\end{array}$ & $\begin{array}{l}-0.832^{* *} \\
(-2.32)\end{array}$ \\
\hline Small Equity Stake 1999 * Post Reform & $\begin{array}{l}-0.427 \\
(-1.03) \\
\end{array}$ & $\begin{array}{l}-0.431 \\
(-1.26) \\
\end{array}$ & $\begin{array}{l}-0.445 \\
(-1.35) \\
\end{array}$ \\
\hline $\begin{array}{l}\text { Observations } \\
\text { Adjusted } R^{2} \\
\end{array}$ & $\begin{array}{l}6365 \\
0.08 \\
\end{array}$ & $\begin{array}{l}6365 \\
0.04 \\
\end{array}$ & $\begin{array}{l}6365 \\
0.04 \\
\end{array}$ \\
\hline $\begin{array}{l}\text { Firm Fixed Effects } \\
\text { Industry-Year F.E. }\end{array}$ & $\begin{array}{l}\text { Yes } \\
\text { Yes }\end{array}$ & $\begin{array}{l}\text { Yes } \\
\text { Yes }\end{array}$ & $\begin{array}{l}\text { Yes } \\
\text { Yes }\end{array}$ \\
\hline
\end{tabular}




\section{Table 8: Differential Effect by whether Equity Stakes have been Sold}

This table displays the main tests splitting the treated group by which fraction of its equity stakes a firm sold. Many Equity Stakes Sold is a dummy variable equal to one if the firm ranks above the median in terms of fraction of equity stakes sold, while Few Equity Stakes Sold is a dummy variable equal to one if the firm ranks below the median. The fraction of equity stakes sold is computed as the EUR value of equity stakes sold divided by the total EUR value of equity stakes. If a company does not own minority equity stakes, these two variables are set equal to zero. Panel A displays regressions for the acquisition probability and is thus the counterpart to Table 4. In regressions 1, I run a logit regression conditional on firm. In regression 2 and 3, I run OLS regressions. Panel B displays regressions for announcement returns (in percentage points) and is thus the counterpart to Table 5 . Panel C displays regressions for the yearly sum of announcement returns (in percentage points) and is thus the counterpart to Table 6. All variables are defined as above. All standard errors are clustered at the firm level. I report tstatistics below the coefficients in parenthesis. ${ }^{* * *},{ }^{* *}, *$ indicate significance at the $1 \%, 5 \%$ and $10 \%$ level.

\section{Panel A: Acquisition Probability}

\begin{tabular}{|c|c|c|c|c|c|c|}
\hline & \multicolumn{6}{|c|}{ Acquisition Dummy } \\
\hline & \multicolumn{2}{|c|}{$(1)$} & \multicolumn{2}{|c|}{$(2)$} & \multicolumn{2}{|c|}{ (3) } \\
\hline Many Equity Stakes Sold* Post Reform & \multicolumn{2}{|c|}{$\begin{array}{c}0.915^{* * *} \\
(2.66)\end{array}$} & \multicolumn{2}{|c|}{$0.107^{* * *}$} & \multicolumn{2}{|c|}{$\begin{array}{c}0.103^{* * *} \\
(2.68)\end{array}$} \\
\hline Few Equity Stakes Sold * Post Reform & \multicolumn{2}{|c|}{0.352} & \multicolumn{2}{|c|}{$(1.28)$} & \multicolumn{2}{|c|}{$\begin{array}{l}0.054 \\
(1.50)\end{array}$} \\
\hline Size * Post Reform & \multicolumn{2}{|c|}{0.060} & \multicolumn{2}{|c|}{-0.004} & \multicolumn{2}{|c|}{$\begin{array}{l}-0.003 \\
(-0.73)\end{array}$} \\
\hline Leverage * Post Reform & \multicolumn{2}{|c|}{$-1.382^{* *}$} & \multicolumn{2}{|c|}{$-0.135^{* *}$} & \multicolumn{2}{|c|}{$-0.142^{* * *}$} \\
\hline Tobin's Q * Post Reform & \multicolumn{2}{|c|}{$\begin{array}{l}-0.174^{*} \\
(-1.82)\end{array}$} & \multicolumn{2}{|c|}{$\begin{array}{l}-0.006 \\
(-0.84)\end{array}$} & \multicolumn{2}{|c|}{$(-0.73)$} \\
\hline $\begin{array}{l}\text { Observations } \\
\text { Adjusted } R^{2}\end{array}$ & \multicolumn{2}{|c|}{3325} & \multicolumn{2}{|c|}{6090} & \multicolumn{2}{|c|}{6090} \\
\hline $\begin{array}{l}\text { Regression Type } \\
\text { Condition on }\end{array}$ & & $\begin{array}{ll}\text { Logit } \\
\mathrm{n}\end{array}$ & & & & \\
\hline $\begin{array}{l}\text { Firm Fixed Effects } \\
\text { Year Fixed Effects } \\
\text { Industry-Year F.E. }\end{array}$ & & & & & & \\
\hline Panel B: Announcement Returns & & & & & & \\
\hline & $\begin{array}{r}\text { Announc } \\
\mathrm{t}-1 \\
\end{array}$ & $\begin{array}{l}\text { t Return } \\
-1\end{array}$ & $\begin{array}{r}\text { Announce } \\
\text { Alpl } \\
\end{array}$ & $\begin{array}{l}\text { ne-Factor } \\
\mathrm{t}+1\end{array}$ & $\begin{array}{r}\text { Announce } \\
\text { Alp } \\
\end{array}$ & $\begin{array}{l}\text { our-Factor } \\
\mathrm{t}+1\end{array}$ \\
\hline & $(1)$ & $(2)$ & $(3)$ & $(4)$ & $(5)$ & $(6)$ \\
\hline Many Equity Stakes Sold* Post Reform & $\begin{array}{l}-1.39^{* *} \\
(-2.03)\end{array}$ & $\begin{array}{l}-1.51^{* *} \\
(-2.13)\end{array}$ & $\begin{array}{l}-1.29^{* *} \\
(-2.15)\end{array}$ & $\begin{array}{l}-1.40^{* *} \\
(-2.26)\end{array}$ & $\begin{array}{l}-1.20^{* *} \\
(-1.99)\end{array}$ & $\begin{array}{l}-1.30^{* *} \\
(-2.10)\end{array}$ \\
\hline Few Equity Stakes Sold * Post Reform & $\begin{array}{l}-1.04^{*} \\
(-1.76)\end{array}$ & $\begin{array}{l}-1.06^{*} \\
(-1.76)\end{array}$ & $\begin{array}{l}-0.76 \\
(-1.43)\end{array}$ & $\begin{array}{l}-0.79 \\
(-1.45)\end{array}$ & $\begin{array}{l}-0.73 \\
(-1.46)\end{array}$ & $\begin{array}{l}-0.75 \\
(-1.46)\end{array}$ \\
\hline Avg. Return $(-365,-20)$ & $\begin{array}{c}1.40^{*} \\
(1.85)\end{array}$ & $\begin{array}{l}1.48^{*} \\
(1.94)\end{array}$ & $\begin{array}{c}1.07 \\
(1.20)\end{array}$ & $\begin{array}{l}1.17 \\
(1.31)\end{array}$ & $\begin{array}{c}0.93 \\
(1.03)\end{array}$ & $\begin{array}{c}1.03 \\
(1.15)\end{array}$ \\
\hline Size * Post Reform & $\begin{array}{l}0.16 \\
(1.12)\end{array}$ & $\begin{array}{c}0.23 \\
(1.55)\end{array}$ & $\begin{array}{c}0.20 \\
(1.36)\end{array}$ & $\begin{array}{l}0.24^{*} \\
(1.66)\end{array}$ & $\begin{array}{c}0.20 \\
(1.42)\end{array}$ & $\begin{array}{c}0.24^{*} \\
(1.70)\end{array}$ \\
\hline Leverage * Post Reform & $\begin{array}{c}0.12 \\
(0.12)\end{array}$ & $\begin{array}{c}0.24 \\
(0.22)\end{array}$ & $\begin{array}{c}-0.38 \\
(-0.36)\end{array}$ & $\begin{array}{c}-0.30 \\
(-0.28)\end{array}$ & $\begin{array}{c}0.15 \\
(0.15)\end{array}$ & $\begin{array}{c}0.20 \\
(0.20)\end{array}$ \\
\hline Tobin's Q * Post Reform & $\begin{array}{l}-0.53^{* *} \\
(-2.41)\end{array}$ & $\begin{array}{l}-0.55^{* *} \\
(-2.54)\end{array}$ & $\begin{array}{c}-0.40^{*} \\
(-1.71)\end{array}$ & $\begin{array}{l}-0.41^{*} \\
(-1.77)\end{array}$ & $\begin{array}{c}-0.31 \\
(-1.40)\end{array}$ & $\begin{array}{c}-0.32 \\
(-1.45)\end{array}$ \\
\hline Cash Acquisition & & $\begin{array}{c}-0.29 \\
(-0.59)\end{array}$ & & $\begin{array}{c}-0.32 \\
(-0.69)\end{array}$ & & $\begin{array}{c}-0.29 \\
(-0.66)\end{array}$ \\
\hline No Payment Information & & $\begin{array}{c}-0.54 \\
(-1.04)\end{array}$ & & $\begin{array}{c}-0.56 \\
(-1.22)\end{array}$ & & $\begin{array}{c}-0.58 \\
(-1.30)\end{array}$ \\
\hline Diversifying Acquisition & & $\begin{array}{c}0.00 \\
(0.02)\end{array}$ & & $\begin{array}{c}0.05 \\
(0.35)\end{array}$ & & $\begin{array}{c}0.05 \\
(0.32)\end{array}$ \\
\hline Cross-Border Deal & & $\begin{array}{c}-0.18 \\
(-0.80)\end{array}$ & & $\begin{array}{l}-0.32^{* *} \\
(-2.01)\end{array}$ & & $\begin{array}{l}-0.35^{* *} \\
(-2.19)\end{array}$ \\
\hline Public Target & & $\begin{array}{l}-0.49^{* *} \\
(-2.29)\end{array}$ & & $\begin{array}{c}-0.11 \\
(-0.68)\end{array}$ & & $\begin{array}{c}-0.04 \\
(-0.26)\end{array}$ \\
\hline Independent Target & & $\begin{array}{l}-0.50^{* * *} \\
(-3.23) \\
\end{array}$ & & $\begin{array}{l}-0.49^{* * *} \\
(-3.46) \\
\end{array}$ & & $\begin{array}{l}-0.46^{* * *} \\
(-3.18) \\
\end{array}$ \\
\hline Observations & 2885 & 2862 & 2852 & 2829 & 2852 & 2829 \\
\hline Adjusted $R^{2}$ & 0.10 & 0.11 & 0.12 & 0.13 & 0.12 & 0.13 \\
\hline Firm Fixed Effects & Yes & Yes & Yes & Yes & Yes & Yes \\
\hline Industry-Year F.E. & Yes & Yes & Yes & Yes & Yes & Yes \\
\hline
\end{tabular}


Panel C: Yearly Sum of Announcement Returns

\begin{tabular}{|c|c|c|c|}
\hline & $\begin{array}{c}\text { Yearly Sum of } \\
\text { Announcement } \\
\text { Returns }\end{array}$ & $\begin{array}{c}\text { Yearly Sum of } \\
\text { Announcement } \\
\text { One-Factor Alphas }\end{array}$ & $\begin{array}{c}\text { Yearly Sum of } \\
\text { Announcement } \\
\text { Four-Factor Alphas }\end{array}$ \\
\hline & $(1)$ & $(2)$ & $(3)$ \\
\hline Many Equity Stakes Sold* Post Reform & $\begin{array}{l}-0.759^{*} \\
(-1.84)\end{array}$ & $\begin{array}{c}-0.662^{* *} \\
(-2.06)\end{array}$ & $\begin{array}{l}-0.634^{*} \\
(-1.89)\end{array}$ \\
\hline Few Equity Stakes Sold * Post Reform & $\begin{array}{l}-0.361 \\
(-0.97)\end{array}$ & $\begin{array}{l}-0.520 \\
(-1.51)\end{array}$ & $\begin{array}{l}-0.607^{*} \\
(-1.80)\end{array}$ \\
\hline Observations & 6365 & 6365 & 6365 \\
\hline Adjusted $R^{2}$ & 0.08 & 0.04 & 0.04 \\
\hline Firm Fixed Effects & Yes & Yes & Yes \\
\hline Industry-Year F.E. & Yes & Yes & Yes \\
\hline
\end{tabular}

\section{Table 9: Capital Expenditures}

This table displays yearly panel regressions of capital expenditures divided by assets (in percentage points) on the interaction of Equity Stake 1999 and Post Reform. In Regressions 3 and 4, I restrict the sample to non-financial companies (one-digit SIC code is different from 6). All independent variables are defined as above. All standard errors are clustered at the firm level. I report t-statistics below the coefficients in parenthesis. $* * *, * *, *$ indicate significance at the $1 \%, 5 \%$ and $10 \%$ level.

\begin{tabular}{|c|c|c|c|c|}
\hline & \multicolumn{4}{|c|}{ Capital Expenditures } \\
\hline & \multicolumn{2}{|c|}{ Full Sample } & \multicolumn{2}{|c|}{ Non-Financial Companies } \\
\hline & $(1)$ & $(2)$ & $(3)$ & $(4)$ \\
\hline \multirow[t]{2}{*}{ Equity Stake $1999 *$ Post Reform } & $1.140^{* *}$ & $1.258^{* * *}$ & 0.679 & 0.668 \\
\hline & $(2.57)$ & $(2.64)$ & (1.33) & $(1.25)$ \\
\hline \multirow[t]{2}{*}{ Size * Post Reform } & -0.096 & -0.066 & -0.155 & -0.119 \\
\hline & $(-0.84)$ & $(-0.55)$ & $(-1.11)$ & $(-0.80)$ \\
\hline \multirow[t]{2}{*}{ Leverage * Post Reform } & $-1.790^{*}$ & $-2.030^{* *}$ & -1.915 & $-2.172^{*}$ \\
\hline & $(-1.87)$ & $(-2.05)$ & $(-1.55)$ & $(-1.70)$ \\
\hline \multirow[t]{2}{*}{ Tobin's Q * Post Reform } & 0.076 & 0.079 & $0.314^{*}$ & 0.323 \\
\hline & $(0.47)$ & $(0.44)$ & $(1.72)$ & $(1.61)$ \\
\hline Observations & 5762 & 5762 & 4890 & 4890 \\
\hline Adjusted $R^{2}$ & 0.08 & 0.08 & 0.35 & 0.36 \\
\hline Firm Fixed Effects & Yes & Yes & Yes & Yes \\
\hline Year Fixed Effects & Yes & No & Yes & No \\
\hline Industry-Year F.E. & No & Yes & No & Yes \\
\hline
\end{tabular}

\section{Table 10: Dividends}

This table displays yearly panel regressions of dividends divided by total assets (in percentage points) on the interaction of Equity Stake 1999 and Post Reform. In Regressions 3 and 4, I restrict the sample to non-financial companies (one-digit SIC code is different from 6). All independent variables are defined as above. All standard errors are clustered at the firm level. I report t-statistics below the coefficients in parenthesis. $* * *, * *, *$ indicate significance at the $1 \%, 5 \%$ and $10 \%$ level.

\begin{tabular}{|c|c|c|c|c|}
\hline & \multicolumn{4}{|c|}{ Dividends } \\
\hline & \multicolumn{2}{|c|}{ Full Sample } & \multicolumn{2}{|c|}{ Non-Financial Companies } \\
\hline & $(1)$ & $(2)$ & $(3)$ & $(4)$ \\
\hline \multirow[t]{2}{*}{ Equity Stake $1999 *$ Post Reform } & 0.122 & 0.155 & 0.112 & 0.147 \\
\hline & $(0.65)$ & $(0.80)$ & $(0.47)$ & $(0.62)$ \\
\hline \multirow[t]{2}{*}{ Size * Post Reform } & $0.073^{*}$ & 0.049 & $0.115^{* *}$ & 0.088 \\
\hline & $(1.73)$ & $(1.16)$ & $(2.15)$ & $(1.60)$ \\
\hline \multirow[t]{2}{*}{ Leverage * Post Reform } & -0.147 & -0.187 & -0.047 & -0.115 \\
\hline & $(-0.40)$ & $(-0.50)$ & $(-0.09)$ & $(-0.21)$ \\
\hline \multirow[t]{2}{*}{ Tobin's Q * Post Reform } & 0.095 & $0.122^{*}$ & 0.107 & $0.143^{*}$ \\
\hline & $(1.50)$ & $(1.89)$ & $(1.37)$ & $(1.81)$ \\
\hline Observations & 5941 & 5941 & 4925 & 4925 \\
\hline Adjusted $R^{2}$ & 0.42 & 0.42 & 0.42 & 0.43 \\
\hline Firm Fixed Effects & Yes & Yes & Yes & Yes \\
\hline Year Fixed Effects & Yes & No & Yes & No \\
\hline Industry-Year F.E. & No & Yes & No & Yes \\
\hline
\end{tabular}




\section{Table 11: Robustness Check: Matched Sample}

This table displays the main tests for a matched subsample. For each company with a minority stake, I select the company in the same FF10 industry which has the closest market capitalization (without replacement). Panel A displays regressions for the acquisition probability and is thus the counterpart to Table 4. Regression 1 is a logit regression conditional on firms. Regressions 2 and 3 are OLS regressions. Panel B displays regressions for announcement returns (in percentage points) and is thus the counterpart to Table 5. Panel C displays regressions for the yearly sum of announcement returns (in percentage points) and is thus the counterpart to Table 6. All variables are defined as above. All standard errors are clustered at the firm level. I report t-statistics below the coefficients in parenthesis. $* * *, * *, *$ indicate significance at the $1 \%, 5 \%$ and $10 \%$ level.

Panel A: Acquisition Probability

Acquisition Dummy

\begin{tabular}{lccc} 
& $(1)$ & $(2)$ & $(3)$ \\
\cline { 2 - 4 } & $0.696^{*}$ & $0.072^{* *}$ & $0.074^{* *}$ \\
\hline Equity Stake 1999 * Post Reform & $(1.84)$ & $(2.15)$ & $(2.09)$ \\
& 0.041 & -0.001 & 0.000 \\
Size * Post Reform & $(0.45)$ & $(-0.20)$ & $(0.03)$ \\
& -1.226 & -0.123 & -0.125 \\
Leverage * Post Reform & $(-1.31)$ & $(-1.38)$ & $(-1.34)$ \\
Tobin's Q * Post Reform & -0.136 & -0.011 & -0.012 \\
& $(-1.05)$ & $(-0.81)$ & $(-0.84)$ \\
\hline Observations & 1617 & 2738 & 2738 \\
Adjusted $R^{2}$ & - & 0.49 & 0.50 \\
\hline Regression Type & Cond. Logit & OLS & OLS \\
Condition on & Firm & & Yes \\
\hline Firm Fixed Effects & No & Yes & No \\
Year Fixed Effects & Yes & No & Yes \\
Industry-Year F.E. & No & & \\
\hline
\end{tabular}

Panel B: Announcement Returns

\begin{tabular}{|c|c|c|c|c|c|c|}
\hline & \multicolumn{2}{|c|}{$\begin{array}{c}\text { Announcement Return } \\
\mathrm{t}-1 \text { to } \mathrm{t}+1\end{array}$} & \multicolumn{2}{|c|}{$\begin{array}{l}\text { Announcement One-Factor } \\
\text { Alpha } t-1 \text { to } t+1\end{array}$} & \multicolumn{2}{|c|}{$\begin{array}{l}\text { Announcement Four-Factor } \\
\text { Alpha } \mathrm{t}-1 \text { to } \mathrm{t}+1\end{array}$} \\
\hline & $(1)$ & $(2)$ & (3) & (4) & (5) & $(6)$ \\
\hline Equity Stake $1999 *$ Post Reform & $\begin{array}{l}-1.50^{* *} \\
(-2.59)\end{array}$ & $\begin{array}{l}-1.57^{* * *} \\
(-2.63)\end{array}$ & $\begin{array}{l}-1.16^{* *} \\
(-2.30)\end{array}$ & $\begin{array}{l}-1.23^{* *} \\
(-2.40)\end{array}$ & $\begin{array}{l}-1.14^{* *} \\
(-2.36)\end{array}$ & $\begin{array}{l}-1.21^{* *} \\
(-2.46)\end{array}$ \\
\hline Avg. Return $(-365,-20)$ & $\begin{array}{c}0.34 \\
(0.48)\end{array}$ & $\begin{array}{l}0.44 \\
(0.61)\end{array}$ & $\begin{array}{l}-0.63 \\
(-0.87)\end{array}$ & $\begin{array}{l}-0.48 \\
(-0.65)\end{array}$ & $\begin{array}{l}-0.77 \\
(-0.95)\end{array}$ & $\begin{array}{l}-0.62 \\
(-0.75)\end{array}$ \\
\hline Size * Post Reform & $\begin{array}{c}0.08 \\
(0.54)\end{array}$ & $\begin{array}{c}0.13 \\
(0.89)\end{array}$ & $\begin{array}{c}0.10 \\
(0.76)\end{array}$ & $\begin{array}{c}0.14 \\
(1.01)\end{array}$ & $\begin{array}{c}0.09 \\
(0.73)\end{array}$ & $\begin{array}{c}0.12 \\
(0.94)\end{array}$ \\
\hline Leverage * Post Reform & $\begin{array}{c}0.15 \\
(0.15)\end{array}$ & $\begin{array}{c}0.21 \\
(0.20)\end{array}$ & $\begin{array}{l}-0.56 \\
(-0.54)\end{array}$ & $\begin{array}{l}-0.52 \\
(-0.49)\end{array}$ & $\begin{array}{l}-0.09 \\
(-0.10)\end{array}$ & $\begin{array}{l}-0.07 \\
(-0.07)\end{array}$ \\
\hline Tobin's Q * Post Reform & $\begin{array}{l}-0.56^{* * *} \\
(-2.79)\end{array}$ & $\begin{array}{l}-0.59^{* * * *} \\
(-2.91)\end{array}$ & $\begin{array}{l}-0.48^{* *} \\
(-2.39)\end{array}$ & $\begin{array}{l}-0.50^{* *} \\
(-2.50)\end{array}$ & $\begin{array}{l}-0.42^{* *} \\
(-2.16)\end{array}$ & $\begin{array}{l}-0.44^{* *} \\
(-2.27)\end{array}$ \\
\hline Cash Acquisition & & $\begin{array}{l}-0.34 \\
(-0.71)\end{array}$ & & $\begin{array}{l}-0.25 \\
(-0.58)\end{array}$ & & $\begin{array}{l}-0.25 \\
(-0.60)\end{array}$ \\
\hline No Payment Information & & $\begin{array}{l}-0.51 \\
(-1.00)\end{array}$ & & $\begin{array}{l}-0.44 \\
(-1.05)\end{array}$ & & $\begin{array}{l}-0.47 \\
(-1.19)\end{array}$ \\
\hline Diversifying Acquisition & & $\begin{array}{c}-0.09 \\
(-0.48)\end{array}$ & & $\begin{array}{c}0.03 \\
(0.16)\end{array}$ & & $\begin{array}{c}0.01 \\
(0.07)\end{array}$ \\
\hline Cross-Border Deal & & $\begin{array}{l}0.07 \\
(0.28)\end{array}$ & & $\begin{array}{l}-0.12 \\
(-0.77)\end{array}$ & & $\begin{array}{l}-0.15 \\
(-0.97)\end{array}$ \\
\hline Public Target & & $\begin{array}{l}-0.45^{* *} \\
(-2.10)\end{array}$ & & $\begin{array}{c}-0.10 \\
(-0.63)\end{array}$ & & $\begin{array}{c}-0.02 \\
(-0.12)\end{array}$ \\
\hline Independent Target & & $\begin{array}{l}-0.40^{* * * *} \\
(-2.65)\end{array}$ & & $\begin{array}{l}-0.37^{* * *} \\
(-2.91)\end{array}$ & & $\begin{array}{l}-0.33^{* * *} \\
(-2.54)\end{array}$ \\
\hline Observations & 2382 & 2360 & 2362 & 2340 & 2362 & 2340 \\
\hline Adjusted $R^{2}$ & 0.07 & 0.08 & 0.08 & 0.09 & 0.10 & 0.11 \\
\hline Firm Fixed Effects & Yes & Yes & Yes & Yes & Yes & Yes \\
\hline Industry-Year F.E. & Yes & Yes & Yes & Yes & Yes & Yes \\
\hline
\end{tabular}

Panel C: Yearly Sum of Announcement Returns

\begin{tabular}{|c|c|c|c|}
\hline & $\begin{array}{c}\text { Yearly Sum of } \\
\text { Announcement Returns }\end{array}$ & $\begin{array}{c}\text { Yearly Sum of } \\
\text { Announcement } \\
\text { One-Factor Alphas }\end{array}$ & $\begin{array}{l}\text { Yearly Sum of Announcement } \\
\text { Four-Factor Alphas }\end{array}$ \\
\hline & $(1)$ & $(2)$ & (3) \\
\hline Equity Stake 1999 * Post Reform & $\begin{array}{c}-0.896^{* *} \\
(-2.34)\end{array}$ & $\begin{array}{c}-0.739^{* *} \\
(-2.29)\end{array}$ & $\begin{array}{c}-0.829^{* *} \\
(-2.45)\end{array}$ \\
\hline Observations & 2802 & 2802 & 2802 \\
\hline Adjusted $R^{2}$ & 0.09 & 0.05 & 0.07 \\
\hline Firm Fixed Effects & Yes & Yes & Yes \\
\hline Industry-Year F.E. & Yes & Yes & Yes \\
\hline
\end{tabular}




\section{Table 12: Robustness Check - Shorter Sample Period}

This table displays the main tests for a shorter sample period from 1996 to 2005. Panel A displays regressions for the acquisition probability and is thus the counterpart to Table 4. Regression 1 is a logit regressions conditional on firms. Regressions 2 and 3 are OLS regressions. Panel $\mathrm{B}$ displays regressions for announcement returns (in percentage points) and is thus the counterpart to Table 5. Panel C displays regressions for the yearly sum of announcement returns (in percentage points) and is thus the counterpart to Table 6. All variables are defined as above. All standard errors are clustered at the firm level. I report t-statistics below the coefficients in parenthesis. ***, **, * indicate significance at the $1 \%, 5 \%$ and $10 \%$ level.

Panel A: Acquisition Probability

Acquisition Dummy

\begin{tabular}{|c|c|c|c|}
\hline & \\
\hline & $(1)$ & $(2)$ & (3) \\
\hline \multirow[t]{2}{*}{ Equity Stake $1999 *$ Post Reform } & $0.690^{*}$ & $0.074^{* *}$ & $0.076^{* *}$ \\
\hline & $(1.94)$ & $(2.29)$ & $(2.11)$ \\
\hline \multirow[t]{2}{*}{ Size * Post Reform } & 0.012 & -0.008 & -0.008 \\
\hline & $(0.12)$ & $(-1.42)$ & $(-1.39)$ \\
\hline \multirow[t]{2}{*}{ Leverage * Post Reform } & $-1.586^{* *}$ & $-0.143^{* * *}$ & $-0.167^{* * * *}$ \\
\hline & $(-2.13)$ & $(-2.47)$ & $(-2.83)$ \\
\hline \multirow[t]{2}{*}{ Tobin's Q * Post Reform } & -0.181 & -0.007 & -0.006 \\
\hline & $(-1.63)$ & $(-0.85)$ & $(-0.69)$ \\
\hline Observations & 1933 & 4207 & 4207 \\
\hline Adjusted $R^{2}$ & & 0.44 & 0.44 \\
\hline Regression Type & Cond. Logit & OLS & OLS \\
\hline Condition on & Firm & & \\
\hline Firm Fixed Effects & No & Yes & Yes \\
\hline Year Fixed Effects & Yes & Yes & No \\
\hline Industry-Year F.E. & No & No & Yes \\
\hline
\end{tabular}

Panel B: Announcement Returns

\begin{tabular}{|c|c|c|c|c|c|c|}
\hline & \multicolumn{2}{|c|}{$\begin{array}{l}\text { Announcement Return } \\
\mathrm{t}-1 \text { to } \mathrm{t}+1\end{array}$} & \multicolumn{2}{|c|}{$\begin{array}{l}\text { Announcement One-Factor } \\
\text { Alpha t- } 1 \text { to } t+1 \\
\end{array}$} & \multicolumn{2}{|c|}{$\begin{array}{l}\text { Announcement Four-Factor } \\
\text { Alpha } t-1 \text { to } t+1\end{array}$} \\
\hline & $(1)$ & $(2)$ & $(3)$ & (4) & $(5)$ & $(6)$ \\
\hline \multirow[t]{2}{*}{ Equity Stake $1999 *$ Post Reform } & -1.25 & -1.30 & -0.97 & -1.06 & -0.88 & -0.95 \\
\hline & $(-1.58)$ & $(-1.60)$ & $(-1.30)$ & $(-1.38)$ & $(-1.22)$ & $(-1.30)$ \\
\hline \multirow[t]{2}{*}{ Avg. Return $(-365,-20)$} & 1.01 & 1.08 & 0.45 & 0.56 & 0.34 & 0.47 \\
\hline & $(1.24)$ & $(1.28)$ & $(0.45)$ & $(0.55)$ & $(0.36)$ & $(0.49)$ \\
\hline \multirow[t]{2}{*}{ Size * Post Reform } & 0.04 & 0.11 & 0.09 & 0.15 & 0.13 & 0.18 \\
\hline & $(0.22)$ & $(0.55)$ & $(0.44)$ & $(0.72)$ & $(0.64)$ & $(0.93)$ \\
\hline \multirow[t]{2}{*}{ Leverage $*$ Post Reform } & -0.90 & -0.92 & -0.90 & -0.92 & -0.13 & -0.19 \\
\hline & $(-0.67)$ & $(-0.67)$ & $(-0.63)$ & $(-0.64)$ & $(-0.10)$ & $(-0.14)$ \\
\hline \multirow[t]{2}{*}{ Tobin's Q * Post Reform } & $-1.04^{* * * *}$ & $-1.06^{* * *}$ & $-0.82^{* * *}$ & $-0.83^{* * *}$ & $-0.69^{* *}$ & $-0.69^{* *}$ \\
\hline & $(-3.93)$ & $(-4.02)$ & $(-2.80)$ & $(-2.83)$ & $(-2.49)$ & $(-2.50)$ \\
\hline \multirow[t]{2}{*}{ Cash Acquisition } & & -0.01 & & -0.10 & & -0.05 \\
\hline & & $(-0.02)$ & & $(-0.20)$ & & $(-0.11)$ \\
\hline \multirow[t]{2}{*}{ No Payment Information } & & -0.21 & & -0.29 & & -0.31 \\
\hline & & $(-0.39)$ & & $(-0.58)$ & & $(-0.65)$ \\
\hline \multirow[t]{2}{*}{ Diversifying Acquisition } & & 0.04 & & 0.07 & & 0.08 \\
\hline & & $(0.17)$ & & $(0.36)$ & & $(0.38)$ \\
\hline \multirow[t]{2}{*}{ Cross-Border Deal } & & -0.10 & & -0.27 & & -0.31 \\
\hline & & $(-0.33)$ & & $(-1.27)$ & & $(-1.47)$ \\
\hline \multirow[t]{2}{*}{ Public Target } & & $-0.66^{* *}$ & & -0.17 & & -0.08 \\
\hline & & $(-2.23)$ & & $(-0.94)$ & & $(-0.41)$ \\
\hline \multirow[t]{2}{*}{ Independent Target } & & $-0.57^{* * *}$ & & $-0.63^{* * *}$ & & $-0.59^{* * *}$ \\
\hline & & $(-2.70)$ & & $(-3.28)$ & & $(-3.05)$ \\
\hline Observations & 2010 & 1998 & 1982 & 1970 & 1982 & 1970 \\
\hline Adjusted $R^{2}$ & 0.12 & 0.13 & 0.14 & 0.15 & 0.15 & 0.16 \\
\hline Firm Fixed Effects & Yes & Yes & Yes & Yes & Yes & Yes \\
\hline Industry-Year F.E. & Yes & Yes & Yes & Yes & Yes & Yes \\
\hline \multicolumn{7}{|c|}{ Panel C: Yearly Sum of Announcement Returns } \\
\hline & \multirow{2}{*}{\multicolumn{2}{|c|}{$\begin{array}{c}\text { Yearly Sum of } \\
\text { Announcement Returns }\end{array}$}} & \multirow{2}{*}{\multicolumn{2}{|c|}{$\begin{array}{c}\text { Yearly Sum of } \\
\text { Announcement } \\
\text { One-Factor Alphas } \\
\end{array}$}} & \multirow{2}{*}{\multicolumn{2}{|c|}{$\begin{array}{l}\text { Yearly Sum of Announcement } \\
\text { Four-Factor Alphas }\end{array}$}} \\
\hline & & & & & & \\
\hline & \multicolumn{2}{|c|}{$(1)$} & \multicolumn{2}{|c|}{$(2)$} & \multicolumn{2}{|c|}{ (3) } \\
\hline \multirow[t]{2}{*}{ Equity Stake $1999 *$ Post Reform } & \multicolumn{2}{|c|}{$-1.207^{* * *}$} & \multicolumn{2}{|c|}{$-0.889^{* * *}$} & \multicolumn{2}{|c|}{$-0.929^{* * *}$} \\
\hline & \multicolumn{2}{|c|}{$(-3.01)$} & \multicolumn{2}{|c|}{$(-2.68)$} & & \\
\hline Observations & & & & & & \\
\hline Adjusted $R^{2}$ & & & & & & \\
\hline Firm Fixed Effects & & & & & & \\
\hline Industry-Year F.E. & & & & & & \\
\hline
\end{tabular}




\section{Table 13: Robustness Check - Controlling for Reverse Equity Stakes}

This table displays the main tests with an additional control for whether part of the firm's own equity is held via minority equity stakes. The additional control is Reverse Equity Stake 1999 interacted with Post Reform. Reverse Equity Stake 1999 is a dummy variable equal to one if a publicly listed German firm holds an equity stake of $20 \%$ or less in the firm in December 1999. Panel A displays regressions for the acquisition probability and is thus the counterpart to Table 4. Regression 1 is a logit regressions conditional on firms. Regressions 2 and 3 are OLS regressions. Panel B displays regressions for announcement returns (in percentage points) and is thus the counterpart to Table 5. All variables are defined as above. All standard errors are clustered at the firm level. I report t-statistics below the coefficients in parenthesis. ***, **, * indicate significance at the $1 \%, 5 \%$ and $10 \%$ level.

Panel A: Acquisition Probability

\begin{tabular}{|c|c|c|c|}
\hline & \multicolumn{3}{|c|}{ Acquisition Dummy } \\
\hline & $(1)$ & $(2)$ & $(3)$ \\
\hline \multirow[t]{2}{*}{ Equity Stake $1999 *$ Post Reform } & $0.714^{* *}$ & $0.087^{* * *}$ & $0.092^{* * *}$ \\
\hline & $(2.50)$ & $(3.14)$ & (3.06) \\
\hline \multirow[t]{2}{*}{ Reverse Equity Stake $1999 *$ Post Reform } & $-0.591^{*}$ & $-0.074^{*}$ & $-0.074^{*}$ \\
\hline & $(-1.81)$ & $(-1.81)$ & $(-1.74)$ \\
\hline \multirow[t]{2}{*}{ Size * Post Reform } & 0.112 & 0.001 & 0.002 \\
\hline & $(1.36)$ & $(0.23)$ & $(0.37)$ \\
\hline \multirow[t]{2}{*}{ Leverage $*$ Post Reform } & $-1.153^{*}$ & $-0.111^{* *}$ & $-0.124^{* *}$ \\
\hline & $(-1.85)$ & $(-2.06)$ & $(-2.27)$ \\
\hline \multirow[t]{2}{*}{ Tobin's Q * Post Reform } & $-0.191^{*}$ & -0.008 & -0.007 \\
\hline & $(-1.89)$ & $(-1.05)$ & $(-0.94)$ \\
\hline Observations & 3325 & 6090 & 6090 \\
\hline Adjusted $R^{2}$ & & 0.42 & 0.42 \\
\hline Regression Type & Cond. Logit & OLS & OLS \\
\hline Condition on & Firm & & \\
\hline Firm Fixed Effects & No & Yes & Yes \\
\hline Year Fixed Effects & Yes & Yes & No \\
\hline Industry-Year F.E. & No & No & Yes \\
\hline
\end{tabular}

Panel B: Announcement Returns

\begin{tabular}{|c|c|c|c|c|c|c|}
\hline & \multicolumn{2}{|c|}{$\begin{array}{c}\text { Announcement Return } \\
\text { t- } 1 \text { to } t+1\end{array}$} & \multicolumn{2}{|c|}{$\begin{array}{l}\text { Announcement One-Factor } \\
\text { Alpha } t-1 \text { to } t+1\end{array}$} & \multicolumn{2}{|c|}{$\begin{array}{l}\text { Announcement Four- } \\
\text { Factor Alpha } t-1 \text { to } t+1\end{array}$} \\
\hline & $(1)$ & $(2)$ & $(3)$ & $(4)$ & $(5)$ & $(6)$ \\
\hline \multirow[t]{2}{*}{ Equity Stake $1999 *$ Post Reform } & $-1.16^{* *}$ & $-1.21^{* *}$ & $-0.96^{*}$ & $-1.01^{*}$ & $-0.92^{*}$ & $-0.96^{*}$ \\
\hline & $(-2.04)$ & $(-2.08)$ & $(-1.90)$ & $(-1.96)$ & $(-1.88)$ & $(-1.92)$ \\
\hline \multirow[t]{2}{*}{ Reverse Equity Stake $1999 *$ Post Reform } & 0.28 & 0.35 & 0.18 & 0.27 & 0.04 & 0.12 \\
\hline & $(0.56)$ & $(0.68)$ & $(0.40)$ & $(0.58)$ & $(0.10)$ & $(0.26)$ \\
\hline \multirow[t]{2}{*}{ Avg. Return $(-365,-20)$} & $1.43^{*}$ & $1.51^{* *}$ & 1.09 & 1.19 & 0.94 & 1.05 \\
\hline & $(1.90)$ & $(1.99)$ & $(1.21)$ & $(1.32)$ & $(1.04)$ & $(1.16)$ \\
\hline \multirow[t]{2}{*}{ Size * Post Reform } & 0.10 & 0.15 & 0.15 & 0.17 & 0.18 & 0.20 \\
\hline & $(0.60)$ & $(0.89)$ & $(0.86)$ & $(1.00)$ & $(1.06)$ & $(1.20)$ \\
\hline \multirow[t]{2}{*}{ Leverage * Post Reform } & -0.00 & 0.08 & -0.58 & -0.52 & -0.02 & 0.00 \\
\hline & $(-0.00)$ & $(0.07)$ & $(-0.52)$ & $(-0.47)$ & $(-0.02)$ & $(0.00)$ \\
\hline \multirow[t]{2}{*}{ Tobin's Q * Post Reform } & $-0.51^{* *}$ & $-0.53^{* *}$ & $-0.40^{*}$ & $-0.41^{*}$ & -0.33 & -0.34 \\
\hline & $(-2.21)$ & $(-2.29)$ & $(-1.67)$ & $(-1.68)$ & $(-1.44)$ & $(-1.44)$ \\
\hline \multirow[t]{2}{*}{ Cash Acquisition } & & -0.27 & & -0.29 & & -0.27 \\
\hline & & $(-0.56)$ & & $(-0.65)$ & & $(-0.61)$ \\
\hline \multirow[t]{2}{*}{ No Payment Information } & & -0.54 & & -0.56 & & -0.57 \\
\hline & & $(-1.04)$ & & $(-1.21)$ & & $(-1.29)$ \\
\hline \multirow[t]{2}{*}{ Diversifying Acquisition } & & 0.00 & & 0.06 & & 0.05 \\
\hline & & $(0.02)$ & & $(0.36)$ & & $(0.34)$ \\
\hline \multirow[t]{2}{*}{ Cross-Border Deal } & & -0.18 & & $-0.32^{* *}$ & & $-0.35^{* *}$ \\
\hline & & $(-0.79)$ & & $(-1.98)$ & & $(-2.16)$ \\
\hline \multirow[t]{2}{*}{ Public Target } & & $-0.48^{* *}$ & & -0.10 & & -0.04 \\
\hline & & $(-2.27)$ & & $(-0.63)$ & & $(-0.21)$ \\
\hline \multirow[t]{2}{*}{ Independent Target } & & $-0.50^{* * *}$ & & $-0.49^{* * * *}$ & & $-0.46^{* * *}$ \\
\hline & & $(-3.21)$ & & $(-3.46)$ & & $(-3.19)$ \\
\hline Observations & 2885 & 2862 & 2852 & 2829 & 2852 & 2829 \\
\hline Adjusted $R^{2}$ & 0.10 & 0.11 & 0.12 & 0.13 & 0.12 & 0.13 \\
\hline Firm Fixed Effects & Yes & Yes & Yes & Yes & Yes & Yes \\
\hline Industry-Year F.E. & Yes & Yes & Yes & Yes & Yes & Yes \\
\hline
\end{tabular}




\section{Table 14: Placebo Tax Reform in December 1994}

This table displays a placebo test for the main tests. I use 1990-1994 as the before event sample and 1995-1999 as the after event sample. Panel A displays regressions for the acquisition probability and is thus the counterpart to Table 4. Panel B displays regressions for announcement returns (in percentage points) and is thus the counterpart to Table 5. All variables are defined as above. All standard errors are clustered at the firm level. I report t-statistics below the coefficients in parenthesis. ***, **, * indicate significance at the $1 \%, 5 \%$ and $10 \%$ level.

Panel A: Acquisition Probability

Acquisitions Dummy

\begin{tabular}{|c|c|c|c|}
\hline & & & \\
\hline & $(1)$ & $(2)$ & $(3)$ \\
\hline \multirow[t]{2}{*}{ Equity Stake $1999 *$ Post Reform } & -0.200 & -0.001 & 0.002 \\
\hline & $(-0.55)$ & $(-0.03)$ & $(0.04)$ \\
\hline \multirow[t]{2}{*}{ Size * Post Reform } & $0.177^{*}$ & $0.016^{* *}$ & $0.015^{*}$ \\
\hline & $(1.73)$ & $(2.06)$ & (1.84) \\
\hline \multirow[t]{2}{*}{ Leverage $*$ Post Reform } & 1.063 & 0.117 & $0.149^{*}$ \\
\hline & $(1.24)$ & $(1.56)$ & $(1.92)$ \\
\hline \multirow[t]{2}{*}{ Tobin's Q * Post Reform } & 0.150 & 0.009 & 0.007 \\
\hline & $(1.16)$ & $(0.89)$ & $(0.70)$ \\
\hline Observations & 1436 & 3149 & 3149 \\
\hline Adjusted $R^{2}$ & & 0.43 & 0.44 \\
\hline Regression Type & Cond. Logit & OLS & OLS \\
\hline Condition on & Firm & & \\
\hline Firm Fixed Effects & No & Yes & Yes \\
\hline Year Fixed Effects & Yes & Yes & No \\
\hline Industry-Year F.E. & No & No & Yes \\
\hline
\end{tabular}

Panel B: Announcement Returns

\begin{tabular}{|c|c|c|c|c|c|c|}
\hline & \multicolumn{2}{|c|}{$\begin{array}{c}\text { Announcement } \\
\text { Return t- } 1 \text { to } t+1\end{array}$} & \multicolumn{2}{|c|}{$\begin{array}{c}\text { Announcement One-Factor } \\
\text { Alpha t- } 1 \text { to } t+1\end{array}$} & \multicolumn{2}{|c|}{$\begin{array}{c}\text { Announcement Four-Factor } \\
\text { Alpha t- } 1 \text { to } t+1\end{array}$} \\
\hline & $(1)$ & $(2)$ & (3) & $(4)$ & (5) & (6) \\
\hline \multirow[t]{2}{*}{ Equity Stake $1999 *$ Post Reform } & 0.04 & 0.23 & 0.19 & 0.60 & 0.15 & 0.54 \\
\hline & $(0.06)$ & $(0.29)$ & $(0.21)$ & $(0.63)$ & $(0.16)$ & $(0.56)$ \\
\hline \multirow[t]{2}{*}{ Avg. Return $(-365,-20)$} & -1.24 & $-1.36^{*}$ & $-2.62^{* *}$ & $-2.50^{* *}$ & $-2.30^{* *}$ & $-2.17^{*}$ \\
\hline & $(-1.51)$ & $(-1.73)$ & $(-2.27)$ & $(-2.21)$ & $(-2.04)$ & $(-1.94)$ \\
\hline \multirow[t]{2}{*}{ Size * Post Reform } & 0.16 & 0.13 & 0.07 & 0.01 & 0.07 & 0.00 \\
\hline & $(0.80)$ & $(0.57)$ & $(0.32)$ & $(0.04)$ & $(0.34)$ & $(0.02)$ \\
\hline \multirow[t]{2}{*}{ Leverage $*$ Post Reform } & 1.17 & 1.41 & -0.82 & -0.63 & -0.43 & -0.33 \\
\hline & $(0.70)$ & $(0.79)$ & $(-0.46)$ & $(-0.33)$ & $(-0.24)$ & $(-0.17)$ \\
\hline \multirow[t]{2}{*}{ Tobin's Q * Post Reform } & 0.01 & 0.04 & -0.02 & 0.00 & -0.06 & -0.05 \\
\hline & $(0.05)$ & $(0.14)$ & $(-0.06)$ & $(0.01)$ & $(-0.23)$ & $(-0.17)$ \\
\hline \multirow[t]{2}{*}{ Cash Acquisition } & & -0.39 & & -0.77 & & -0.63 \\
\hline & & $(-0.61)$ & & $(-1.27)$ & & $(-1.04)$ \\
\hline \multirow[t]{2}{*}{ No Payment Information } & & -0.87 & & $-1.08^{*}$ & & -0.92 \\
\hline & & $(-1.33)$ & & $(-1.78)$ & & $(-1.52)$ \\
\hline \multirow[t]{2}{*}{ Diversifying Acquisition } & & 0.23 & & 0.38 & & 0.36 \\
\hline & & $(0.90)$ & & (1.59) & & (1.55) \\
\hline \multirow[t]{2}{*}{ Cross-Border Deal } & & -0.13 & & -0.25 & & $-0.40^{*}$ \\
\hline & & $(-0.41)$ & & $(-1.07)$ & & $(-1.67)$ \\
\hline \multirow[t]{2}{*}{ Public Target } & & $-1.59^{* * *}$ & & $-1.11^{* *}$ & & $-0.90^{*}$ \\
\hline & & $(-2.64)$ & & $(-2.09)$ & & $(-1.78)$ \\
\hline \multirow[t]{2}{*}{ Independent Target } & & $-0.44^{* *}$ & & $-0.47^{* *}$ & & $-0.45^{* *}$ \\
\hline & & $(-2.00)$ & & $(-2.34)$ & & $(-2.18)$ \\
\hline Observations & 1581 & 1572 & 1435 & 1427 & 1435 & 1427 \\
\hline Adjusted $R^{2}$ & 0.14 & 0.15 & 0.17 & 0.18 & 0.17 & 0.18 \\
\hline Firm Fixed Effects & Yes & Yes & Yes & Yes & Yes & Yes \\
\hline Industry-Year F.E. & Yes & Yes & Yes & Yes & Yes & Yes \\
\hline
\end{tabular}




\section{Appendix 1: Variable definitions}

This table displays the variable definitions for all variables used in the regressions. All variables are winsorized at the $1 \%$ and $99 \%$ thresholds.

Panel A: Firm-Year-Level Variables and Year-Level Variables

\begin{tabular}{|c|c|}
\hline Variable Name & Definition \\
\hline Post Reform & Dummy variable equal to one in years 2000 to 2007 and zero in years 1992 to 1999. \\
\hline Acquisition Dummy & $\begin{array}{l}\text { Variable equal to one if the firm undertook an acquisition in the year. I include acquisitions of private } \\
\text { companies, but exclude acquisitions in which the acquirer owns more than } 25 \% \text { before or less than } \\
50 \% \text { after the acquisition. The variable is zero if the firm did not undertake an acquisition in the year, } \\
\text { but was covered in Worldscope or Compustat Global. }\end{array}$ \\
\hline Sum of Announcement Returns & $\begin{array}{l}\text { Sum of acquirer returns from t-1 to } t+1 \text { around the announcement date of all acquisitions the firm } \\
\text { undertook within the year. This variable is set to zero if the firm did not undertake an acquisition in the } \\
\text { year, but was covered in Worldscope or Compustat Global. }\end{array}$ \\
\hline $\begin{array}{l}\text { Yearly Sum of Announcement } \\
\text { One-Factor Alphas }\end{array}$ & $\begin{array}{l}\text { Sum of acquirer one-factor alphas from } t-1 \text { to } t+1 \text { around the announcement date of all acquisitions the } \\
\text { firm undertook within the year. This variable is set to zero if the firm did not undertake an acquisition in } \\
\text { the year, but was covered in Worldscope or Compustat Global. }\end{array}$ \\
\hline $\begin{array}{l}\text { Yearly Sum of Announcement } \\
\text { Four-Factor Alphas }\end{array}$ & $\begin{array}{l}\text { Sum of acquirer four-factor alphas from } \mathrm{t}-1 \text { to } \mathrm{t}+1 \text { around the announcement date of all acquisitions the } \\
\text { firm undertook within the year. This variable is set to zero if the firm did not undertake an acquisition in } \\
\text { the year, but was covered in Worldscope or Compustat Global. }\end{array}$ \\
\hline $\begin{array}{l}\text { Yearly Sum of Residuals (raw } \\
\text { returns) }\end{array}$ & $\begin{array}{l}\text { Sum of residuals from a regression of Announcement Return on Avg. Return (-365,-20), Cash } \\
\text { Acquisition, No Payment Information, Diversifying Acquisition, Cross-Border Deal, Public Target, } \\
\text { Independent Target. The sum is taken over all the acquisition the company undertook in that year. This } \\
\text { variable is set to zero if the firm did not undertake an acquisition in the year, but was covered in } \\
\text { Worldscope or Compustat Global. }\end{array}$ \\
\hline Capital Expenditures & $\frac{\text { Capital Expenditure }}{\text { Assets }}$ \\
\hline Dividends & $\frac{\text { Total Dividends }}{\text { Assets }}$ \\
\hline
\end{tabular}

Panel B: Firm-Level Variables

\begin{tabular}{|c|c|}
\hline Variable Name & Definition \\
\hline Equity Stake 1999 & $\begin{array}{l}\text { Dummy variable equal one if the firm owns at least one equity stake below } 20 \% \text { in another company in } \\
\text { December } 1999 \text {. I also include the equity stakes of subsidiaries if the subsidiary is held at least with } 75 \% \text {. }\end{array}$ \\
\hline Size & $\begin{array}{l}\text { Log (market capitalization) } \\
\text { Where market capitalization is the market value of equity of the firm in December } 1999 .\end{array}$ \\
\hline Leverage & $\begin{array}{l}\frac{\text { Book value of debt }}{\text { Book value of assets }} \\
\text { (in December 1999) }\end{array}$ \\
\hline Tobin’s Q & $\begin{array}{l}\text { Market capitalization } \\
\text { Book value of equity } \\
\text { (in December 1999) }\end{array}$ \\
\hline Industry & 10 Fama-French industry groups \\
\hline Large Equity Stake 1999 & $\begin{array}{l}\text { Dummy variable equal to one if the company is above the median by total EUR size of its minority equity } \\
\text { stakes in 1999. It is equal to zero if the firm is below the median or does not own equity stakes in } 1999 . \\
\text { For equity stakes held in private companies, I estimate the market value of the company by multiplying } \\
\text { the nominal capital ("Kapital") reported in Who owns Whom? with the average ratio of market } \\
\text { capitalization to nominal capital for public firms. }\end{array}$ \\
\hline Small Equity Stake 1999 & $\begin{array}{l}\text { Dummy variable equal to one if the company is below the median by total EUR size of its minority equity } \\
\text { stakes in 1999. It is equal to zero if the firm is above the median or does not own equity stakes in } 1999 . \\
\text { For equity stakes held in private companies, I estimate the market value of the company by multiplying } \\
\text { the nominal capital ("Kapital") reported in Who owns Whom? with the average ratio of market } \\
\text { capitalization to nominal capital for public firms. }\end{array}$ \\
\hline Many Equity Stakes Sold & $\begin{array}{l}\text { Dummy variable equal to one if the company owns equity stakes and is above the median by fraction of } \\
\text { equity stakes sold. It is equal to zero if the firm is below the median or does not own equity stakes in } \\
\text { 1999. The fraction of equity stakes sold is computed as the EUR value of equity stakes sold divided by } \\
\text { the total EUR value of equity stakes. }\end{array}$ \\
\hline Few Equity Stakes Sold & $\begin{array}{l}\text { Dummy variable equal to one if the company owns equity stakes and is below the median by fraction of } \\
\text { equity stakes sold. It is equal to zero if the firm is above the median or does not own equity stakes in } \\
\text { 1999. The fraction of equity stakes sold is computed as the EUR value of equity stakes sold divided by } \\
\text { the total EUR value of equity stakes. }\end{array}$ \\
\hline Reverse Equity Stake 1999 & $\begin{array}{l}\text { Dummy variable equal one if at least one publicly listed German firm owns an equity stake below } 20 \% \\
\text { in this company in December } 1999 \text {. This also includes cases where the equity stake is held through a } \\
\text { chain of subsidiaries at the } 75 \% \text { cut-off. Thus the definition is the same as for Equity Stake 1999, but in } \\
\text { the opposite direction, i.e. it is equal to one if the firm is owned via an equity stake rather than that it } \\
\text { owns an equity stake. }\end{array}$ \\
\hline
\end{tabular}


Panel C: Acquisition-Level Variables

\begin{tabular}{ll}
\hline Variable Name & Definition \\
\hline Announcement Return & $\begin{array}{l}\text { Acquirer announcement return from t-1 to t+1 days around the acquisition announcement day according } \\
\text { to SDC Platinum. }\end{array}$ \\
\hline $\begin{array}{l}\text { One-Factor Announcement } \\
\text { Alpha }\end{array}$ & $\begin{array}{l}\text { Acquirer announcement one-factor alpha from t-1 to t+1 days around the acquisition announcement day } \\
\text { according to SDC Platinum. For a more detailed description see Appendix } 2 .\end{array}$ \\
\hline Three-Factor Announcement & $\begin{array}{l}\text { Acquirer announcement four-factor alpha from t-1 to t+1 days around the acquisition announcement day } \\
\text { according to SDC Platinum. For a more detailed description see Appendix 2. }\end{array}$ \\
\hline Dlpha & Dummy variable equal to one if the acquisition target operates in another 10 Fama-French industry. \\
\hline Cross-Border Deal & Dummy variable equal to one if the acquisition target is not located in Germany. \\
\hline Cash Acquisition & $\begin{array}{l}\text { Dummy variable equal to one if the consideration listed in SDC Platinum is entirely paid using cash, } \\
\text { capital infusion or debt reduction. If there is no information on payment method, this variable is set to } \\
\text { zero. }\end{array}$ \\
\hline No Payment Information & Dummy variable equal to one if SDC Platinum does not provide information on the payment method. \\
\hline Public Target & Dummy variable equal to one if the acquisition target has a SEDOL. \\
\hline Independent Target & Dummy variable equal to one if there is no parent company of the target listed in SDC Platinum. \\
\hline
\end{tabular}




\section{Appendix 2: Additional Information on Dataset Construction}

\section{Ownership data}

I start constructing my sample using the Who owns Whom? (Wer gehört wem?) database on equity stakes in Germany as of July 1999. I match companies from Who owns Whom? to the other data sources using German security identifiers (Wertpapierkennnummern or WKN) as well as matching by name, since not all publicly listed companies in Who owns Whom? have a security identifier. I control by hand that all matches are correct.

Pyramid structures within corporations, i.e. subsidiaries owning subsidiaries, are common in Germany as they do not have the same tax disadvantages as in the U.S. (Faccio and Lang (2002)). Therefore, I also take into account the equity stakes of subsidiaries. I follow the equity stakes "up the ownership chain" as long as any link consists of at least $75 \%$ ownership. To illustrate: if company A owns company B by at least 75\%, I assign the equity stakes of company B to company A. I make sure that in such a case, company B does not enter the sample to avoid double counting. Basically, company B is treated as a subsidiary of company A and not as an independent company. I choose the threshold of $75 \%$, because $25 \%$ is the threshold for a blocking minority in German corporation law. To illustrate: If company A owns $80 \%$ in company B and company B has a $10 \%$ equity stake in company C, company A is treated as holding $8 \%$ in company $\mathrm{C}$ and company $\mathrm{B}$ is not part of my sample. If A held only 60\%, I would treat the equity stake as a $10 \%$ equity stake belonging to company $\mathrm{B}$.

\section{Value of Equity Stakes}

I estimate the value of an equity stake in 1999 by multiplying the percentage equity owned with my estimate of the firm's market value. The percentage owned is reported in the Who owns Whom? database. For equity stakes in publicly listed firms, I take the market value from Datastream or Computstat Global. For private companies, I estimate the market value using nominal capital (Kapital) as reported by Who owns Whom?. First, I compute the ratio of market value to nominal capital for publicly listed companies. Then, I estimate the market value of private companies by multiplying their nominal capital with this ratio.

\section{Announcement returns}

I use SEDOLs to match mergers and acquisition data from SDC Platinum data to the other datasets. I assign an acquisition to a company if the acquirer's SEDOL or the acquirer's parent SEDOL matches any of the company's SEDOLs or the SEDOL of a company in which the company owns at least 75\%. For stock return data, I use Datastream and Compustat Global. 
Many companies have different share classes. I calculate the announcement returns based on the share class which is listed as "primary share class" on Datastream. Since individual equity return data in Datastream can sometimes have severe errors (Ince and Porter (2004)), I set any daily return in Datastream or Compustat Global whose absolute value is above 20\% to missing. There are many days on which either Datastream or Compustat Global has missing return data. For each company and each month, I choose the source that has fewer missing observations in that month.

To compute alphas, I construct the four-factors of the Carhart (1997) model for Germany following the instructions on the website of Kenneth French ${ }^{11}$. I use the one month Frankfurt interbank rate as the risk-free rate. As the market return, I use the Germany Datastream Index, which consists of 250 German companies. To compute HML, SMB and MOM factors, I use only German companies for which I have market capitalization and a positive book value at the end of the prior year. At the beginning of each year, I split the firms into above/below median in terms of size and in Top 30\%, Bottom 30\% and rest for market-to-book ratio. For the 6 portfolios thus formed, I compute value weighted returns for each day and then compute the factors as:

$S M B=\frac{1}{3} *($ Small Value + Small Neutral + Small Growth $)-\frac{1}{3} *($ Big Value + Big Neutral + Big Growth $)$

$H M L=\frac{1}{2} *($ Small Value + Big Value $)-\frac{1}{2} *($ Small Growth + Big Growth $)$

To compute the MOM factor, I sort firms in each month by market capitalization at the beginning of the year into above/below median and by sum of return on months t-12 to t-2 in Top 30\%, Bottom 30\% and rest. For the firm to be included, the returns over t-12 to t-2 must be based on at least 3 months of data. For the 6 portfolios thus formed, I compute value weighted returns for each day and then compute the momentum factor as:

$M O M=\frac{1}{2} *($ Small High + Big High $)-\frac{1}{2} *($ Small Low + Big Low $)$

For each stock and each month, I then compute the beta with respect to those factors from a regression over the past $\mathrm{t}-12$ to $\mathrm{t}-2$ months. For the one-factor alpha, I compute the beta using the regression:

$r_{c, t}=\alpha+\beta *\left(r_{m, t}-r_{f, t}\right)$

\footnotetext{
${ }^{11}$ http://mba.tuck.dartmouth.edu/pages/faculty/ken.french/data_library.html
} 
Where $r_{c, t}$ is the daily company return, $r_{m, t}$ is the daily market return and $r_{f, t}$ is the daily risk free rate. For the four-factor alpha, I compute the regression:

$r_{c, t}=\alpha+\beta_{m} *\left(r_{m, t}-r_{f, t}\right)+\beta_{H M L} * H M L+\beta_{S M B} * S M B+\beta_{M O M} * M O M$

To compute the announcement return alphas, I use the betas and factors constructed as described above and compute the one-factor alpha as:

One factor alpha ${ }_{c, t}=r_{c, t}-\beta_{c} *\left(r_{m, t}-r_{f, t}\right)$

Where $r_{c, t}$ is the daily company return, $r_{m, t}$ is the daily market return and $r_{f, t}$ is the daily risk free rate. $\beta_{c}$ is the company beta computed over months $\mathrm{t}-12$ to $\mathrm{t}-2$ as described above.

Similarly, I compute the four-factor alpha as:

Four factor alpha $a_{c, t}$

$$
=r_{c, t}-\beta_{c} *\left(r_{m, t}-r_{f, t}\right)-\beta_{H M L} * H M L_{t}-\beta_{S M B} * S M B_{t}-\beta_{M O M} * M O M_{t}
$$

